\title{
Eosinophils in fungus-associated allergic pulmonary disease
}

\section{Sumit Ghosh*, Scott A. Hoselton, Glenn P. Dorsam and Jane M. Schuh}

Department of Veterinary and Microbiological Sciences, North Dakota State University, Fargo, ND, USA

Edited by:

Amr El-Shazly, Liege University

Hospital, Belgium

\section{Reviewed by:}

Amr El-Shazly, Liege University

Hospital, Belgium

Li Cher Loh, Penang Medical College,

Malaysia

\section{*Correspondence:}

Sumit Ghosh, Department of Veterinary and Microbiological

Sciences, North Dakota State University, P. O. Box 6050, Dept 7690,

Fargo, ND 58108-6050, USA.

e-mail: sumit.ghosh@ndsu.edu
Asthma is frequently caused and/or exacerbated by sensitization to fungal allergens, which are ubiquitous in many indoor and outdoor environments. Severe asthma with fungal sensitization is characterized by airway hyperresponsiveness and bronchial constriction in response to an inhaled allergen that is worsened by environmental exposure to airborne fungi and which leads to a disease course that is often very difficult to treat with standard asthma therapies. As a result of complex interactions among inflammatory cells, structural cells, and the intercellular matrix of the allergic lung, patients with sensitization to fungal allergens may experience a greater degree of airway wall remodeling and progressive, accumulated pulmonary dysfunction as part of the disease sequela. From their development in the bone marrow to their recruitment to the lung via chemokine and cytokine networks, eosinophils form an important component of the inflammatory milieu that is associated with this syndrome. Eosinophils are recognized as complex multi-factorial leukocytes with diverse functions in the context of allergic fungal asthma. In this review, we will consider recent advances in our understanding of the molecular mechanisms that are associated with eosinophil development and migration to the allergic lung in response to fungal inhalation, along with the eosinophil's function in the immune response to and the immunopathology attributed to fungus-associated allergic pulmonary disease.

Keywords: allergic asthma, inflammation, eosinophils, fungus

\section{INTRODUCTION}

Increasing recruitment of eosinophils into affected tissues is a cardinal feature of allergic disease. In allergic asthma, the Th2-mediated immune response orchestrates the production of cytokines and chemokines that coordinate to provide an increase in the number of eosinophils that are produced in the bone marrow to travel through the circulatory system to the lung in response to an inhaled allergen challenge. In recent decades, the prevalence of asthma in the U.S. and other industrialized countries has dramatically increased (Lindell et al., 2008). In 2009, asthma afflicted $8.2 \%$ of adults and children in the U.S., 24.6 million persons (Nassenstein et al., 2005; Umetsu and DeKruyff, 2006; Knutsen et al., 2012). In the context of asthma, sensitization to fungi presents a severe clinical scenario that is difficult to treat, accounting for a disproportionately large number of emergency center visits and hospitalizations (Knutsen et al., 2012). Fungal avoidance strategies are often impractical, since fungal spores are ubiquitous in many indoor and outdoor environments and may be found at any time of year. Airway inflammation, marked by a robust eosinophilia, exacerbates asthma symptoms and activates structural cells, which over time changes the architecture of the lung. Metaplasia of the bronchial epithelial layer to mucusproducing goblet cells results in mucus-obstructed airways, and increases in both airway smooth muscle and peribronchial fibrosis often results in significant loss of pulmonary function.

Allergic asthma arises as a result of an immune response triggered by the inhalation of (often) non-infectious environmental antigens. For this reason, respiratory allergies have been classified by many as aberrant immune responses precipitated by a poorly educated immune system or by cross-reactivity to allergens that are similar to host proteins. In their role in the lung, eosinophils, the granulocytes most often associated with allergic asthma, are frequently maligned as participants in the pathogenesis of allergic lung disease. However, recent research suggests that one of the important roles of the eosinophil may be in their ability to carry out important immune functions in the lumen of the airway, a compartment that is not readily accessible by many other cell types. Thus, the eosinophil may be utilized as an antifungal mechanism to prevent infection. This review focuses on the current understanding of the molecular mechanisms that are associated with eosinophil activation, recruitment to the lung, and the function of these multi-factorial granulocytes in allergic/fungus-associated allergic pulmonary disease.

\section{DEVELOPMENT OF EOSINOPHILIA IN FUNGAL ASTHMA}

Eosinophils develop and mature in the bone marrow from CD $34^{+}$ pluripotent progenitor cells under the influence of interleukin3 (IL-3) and granulocyte macrophage colony stimulating factor (GM-CSF), with Interleukin-5 (IL-5) acting as a late differentiation factor (Figure 1). Eosinophil differentiation is induced by the synchronized actions of the transcription factors GATA1 (a zinc finger family member), PU.1 (an Ets family member), and CCAAT/enhancer-binding protein (C/EBP) family members (Hirasawa et al., 2002; McNagny and Graf, 2002; Trivedi and Lloyd, 


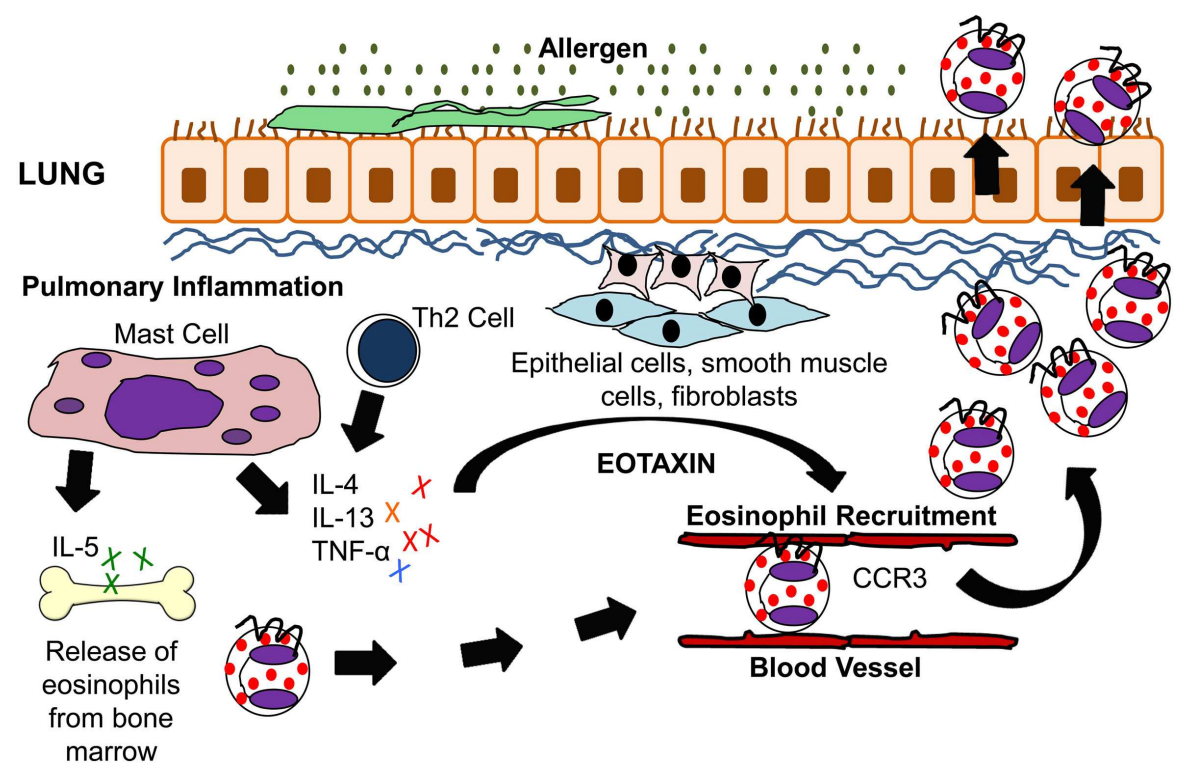

FIGURE 1 | IL-5 and eotaxin-induced eosinophil recruitment in allergic asthma. Inhaled allergens activate Th2 lymphocytes and mast cells to produce the cytokines IL-4, IL-5, IL-13, and TNF- $\alpha$. These cytokines stimulate lung epithelial cells, fibroblasts, and smooth muscle cells to produce eotaxin. IL-5 modulates eosinophil migration from the bone marrow through its action on eotaxin and Th2 cells. Eotaxin on the other hand modulates eosinophil homing to the lung tissue via CCR3 which is present on eosinophils.
2007). The contribution of other transcription factors and subtypes may also be important in eosinophil development but is less well established (McNagny and Graf, 2002).

Even though GATA-1, PU.1, and C/EBP are expressed by a variety of hematopoietic lineages, it is their expression and coordination with a unique cytokine and growth factor cocktail that results in the selective development of eosinophils. IL-3, GM-CSF, and IL-5 are associated with the development of various cells of the myeloid lineage and signal through receptors that share a common $\beta$-chain but have cytokine-specific $\alpha$-chains (Sanderson, 1992; Uhm et al., 2012). All of the three cytokines play a central role in eosinophil development, endothelial adhesion, activation, and survival in fungal asthma. They act upon progenitor cells within the bone marrow as well as mature cells in the periphery.

Eosinophils are typically released to the peripheral blood as fully differentiated mature cells. In non-atopic humans, eosinophils make up less than $1 \%$ of the peripheral leukocytes in the blood. In allergic conditions, newly released eosinophils circulate in the blood for a short period before homing preferentially to the lung, skin, and gut mucosa using eotaxin chemokine signals and the expressed adhesion marker MAdCAM-1 (Walsh, 1999; Uhm et al., 2012). They can persist in the circulation for $8-12 \mathrm{~h}$ and can reside in the tissues for up to 2 weeks through the autocrine production of GM-CSF, which is instigated by the cell's interaction with the extracellular matrix (ECM; Anwar et al., 1993; Uhm et al., 2012).

In the atopic patient, sensitization of the bronchial mucosa signals an increase in eosinophilopoiesis, which provides a ready pool of mature eosinophils that can be released in response to allergen challenge/fungal challenge (Hogaboam et al., 2000, 2005; Hoselton et al., 2010). Although the number of eosinophils is quite variable, they are elevated in the majority of asthmatics and may reach $30 \%$ of the bronchoalveolar lavage (BAL) cells (Wardlaw et al., 2000; Hoselton et al., 2010; Ghosh et al., 2012) that are differentially counted from the airway of asthmatics and $50 \%$ of the cells in an induced sputum specimen (Wardlaw et al., 2000). Along with an increase in the number of mature eosinophils in the periphery, there is mounting evidence that $\mathrm{CD} 34^{+} \mathrm{CD} 45^{+} \mathrm{IL}-$ $5 \mathrm{R} \alpha$ eosinophil progenitor cells may be capable of migrating from the bone marrow to the site of allergic inflammation in asthmatic patients (Robinson et al., 1999; Dorman et al., 2005; Menzies-Gow et al., 2007; Murdock et al., 2012). Similar observations have been reported using murine models of fungal allergic asthma showing that $6 \mathrm{~h}$ after allergen challenge $\mathrm{CD} 34^{+} \mathrm{CD} 45^{+} \mathrm{IL}-5 \mathrm{R} \alpha^{+}$eosinophil progenitor cell populations are elevated in the murine lung (Saito et al., 2002; Johansson et al., 2004; Southam et al., 2005; Murdock et al., 2012; Rosenberg et al., 2013).

\section{ACTIVATION OF EOSINOPHILS AND RECRUITMENT TO THE ALLERGIC LUNG}

Antigen-specific activation of Th2 cells plays an important role in eosinophilic inflammation in allergic asthma, and T cell-deficient mice are protected from lung eosinophilia and airway hyperresponsiveness (AHR; Gavett et al., 1994; Gonzalo et al., 1996). The cytokines IL-4, IL-5, and IL-13, all of which are produced by Th2 cells after fungal allergen challenge, stimulate and enhance the production of eotaxin. Eotaxin then works with the Th2derived cytokine IL-5 in the selective recruitment of eosinophils (Gutierrez-Ramos et al., 1999; Lloyd et al., 2000; Foster et al., 2001). In a murine model of fungal allergic asthma, eotaxin plays a role in the early recruitment of Th2 cells (Schuh et al., 2002). Fungal studies using an Aspergillus fumigatus intratracheal model system 
have demonstrated IL-17's central role in driving eosinophilia in Th2-mediated allergic airway inflammation (Schnyder-Candrian et al., 2006; Murdock et al., 2012). IL-17 has also been shown to induce eotaxin-1 expression in human airway smooth muscle cells (Rahman et al., 2006). A summary of eosinophil trafficking in the allergic lung is shown in Figure 1.

Pro-inflammatory cytokines work in coordination with chemokine that are produced at the sites of chronic inflammation to attract mature eosinophils from the bone marrow (Barnes, 2008). The initiation and maintenance of eosinophil migration depends on the cooperative nature of the chemotactic and chemokinetic signals. The receptor profile on the surface of the eosinophil dictates which, if any, chemoattractants will regulate movement and to what extent migration can be induced. By promoting receptor aggregation and the co-localization of downstream signaling mediators, binding of IL-5, IL-3, and GM-CSF primes eosinophil responses to chemoattractants, allowing movement to be initiated by the chemotactic agent (Simson and Foster, 2000; Uhm et al., 2012). In the case of eosinophils, a number of mediators are known to induce eosinophil migration by inducing chemotactic and/or chemokinetic responses in the cell (Table 1).

\section{IL-5}

Interleukin- 5 is secreted by mast cells and $\mathrm{T}$ cells in the late phase of the inflammatory response and plays a key role in the recruitment of eosinophils from the bone marrow, amplifying the chemoattractant potential of chemokines in the tissues. IL-5 primes eosinophils and amplifies intracellular signaling systems coupled to chemokine receptors. The crosstalk between signal transduction molecules used in these processes serves to generate distinct and/or amplified migratory responses (Simson and Foster, 2000). IL-5 is elevated in fungal allergy and plays a critical role in

Table 1 | Mediators involved in eosinophil migration.

\begin{tabular}{|c|c|c|c|}
\hline Type & Effectiveness & s Function & Reference \\
\hline \multicolumn{4}{|l|}{ CYTOKINES } \\
\hline IL $=5$ & $\begin{array}{l}\text { Moderate } \\
\text { to high }\end{array}$ & $\begin{array}{l}\text { Primes eosinophils, chemotaxis, chemokinesis, } \\
\text { selective, and regulate adhesion pathways }\end{array}$ & $\begin{array}{l}\text { Sanderson (1992), Collins et al. (1995), Mould et al. (1997), Simson } \\
\text { and Foster (2000), and Barnes (2008) }\end{array}$ \\
\hline IL-3 and GM-CSF & Low & $\begin{array}{l}\text { Chemotaxis and increase expression of IL-5R } \\
\text { Non-selective }\end{array}$ & $\begin{array}{l}\text { Sanderson (1992), Mould et al. (1997), Simson and Foster (2000), } \\
\text { Barnes (2008), and Boldajipour et al. (2008) }\end{array}$ \\
\hline $\mathrm{IL}-17$ & Low & & Murdock et al. (2012) \\
\hline \multicolumn{4}{|l|}{ CHEMOKINES } \\
\hline Eotaxins & High & Selective and regulates adhesion pathways & $\begin{array}{l}\text { Collins et al. (1995), Mould et al. (1997), Simson and Foster (2000), } \\
\text { Borchers et al. (2002), and Paplinska et al. (2007) }\end{array}$ \\
\hline $\mathrm{MIP}-1 \alpha$ & High & Primes eosinophils and non-selective & $\begin{array}{l}\text { Schweizer et al. (1996), Simson and Foster (2000), Conti and } \\
\text { Digioacchino (2001), Kayaba and Chihara (2001), and Magalhaes et al. } \\
\text { (2009) }\end{array}$ \\
\hline RANTES & Moderate & Non-selective & $\begin{array}{l}\text { Schweizer et al. (1996), Simson and Foster (2000), Conti and } \\
\text { Digioacchino (2001), and Borchers et al. (2002) }\end{array}$ \\
\hline MCP-3 & High & Non-selective & $\begin{array}{l}\text { Hansel et al. (1993), Rozell et al. (1996), Schweizer et al. (1996), and } \\
\text { Simson and Foster (2000) }\end{array}$ \\
\hline IL-8 & Low & Non-selective & Hansel et al. (1993) and Hamid and Tulic (2009) \\
\hline \multicolumn{4}{|l|}{ LIPIDS } \\
\hline PAF & $\begin{array}{l}\text { Moderate } \\
\text { to High }\end{array}$ & Non-selective & $\begin{array}{l}\text { Morita et al. (1989), Hwang (1990), Simson and Foster (2000), Kato } \\
\text { et al. (2004), and Rosenberg et al. (2007) }\end{array}$ \\
\hline LTB4 & Low & Non-selective & $\begin{array}{l}\text { Morita et al. (1989), Munoz et al. (1997), Simson and Foster (2000), } \\
\text { and Rosenberg et al. (2007) }\end{array}$ \\
\hline LTE4 & Low & Non-selective & $\begin{array}{l}\text { Morita et al. (1989), Munoz et al. (1997), Simson and Foster (2000), } \\
\text { Bandeira-Melo and Weller (2003), and Rosenberg et al. (2007) }\end{array}$ \\
\hline \multicolumn{4}{|c|}{ FUNGAL COMPONENTS } \\
\hline Chitin & Low & Non-selective & Van Dyken et al. (2011) \\
\hline \multicolumn{4}{|c|}{ ANAPHYLATOXINS } \\
\hline C3a & $\begin{array}{l}\text { Moderate } \\
\text { to high }\end{array}$ & Selective & $\begin{array}{l}\text { Daffern et al. (1995), Discipio et al. (1999), and Discipio and } \\
\text { Schraufstatter (2007) }\end{array}$ \\
\hline C5a & $\begin{array}{l}\text { Moderate } \\
\text { to high }\end{array}$ & Non-selective & $\begin{array}{l}\text { Discipio et al. (1999), Guo and Ward (2005), and Discipio and } \\
\text { Schraufstatter (2007) }\end{array}$ \\
\hline
\end{tabular}


the differentiation, proliferation, and maturation of eosinophils in the bone marrow (Templeton et al., 2010). Recent studies have also shown a role of epithelial cell-derived cytokine thymic stromal lymphoprotein (TSLP), IL-25, and IL-33 in promoting eosinophilia by inducing IL-5 production (Rosenberg et al., 2013).

The IL-5 receptor, IL-5R, is expressed only on eosinophils and basophils (Robinson et al., 1999; Christodoulopoulos et al., 2000; Menzies-Gow et al., 2003, 2007). The expression of IL-5R on eosinophils is closely regulated and depends upon the activation state and anatomical location of the cell. For example, human umbilical cord-derived $\mathrm{CD}_{3}{ }^{+}$cells stimulated with IL3, IL-5, and GM-CSF leads to the up-regulation of IL-5R $\alpha$; an important step in eosinophil lineage commitment (Tavernier et al., 2000). However, its expression is downregulated on mature human eosinophils when treated the same cocktail of cytokines (Gregory et al., 2003). Although the receptors are found on a wider range of cells, administration of IL-3 and GM-CSF has been shown to promote eosinophil production in animal models, as well as in clinical trials (Sanderson, 1992; Ueno et al., 1994; Takamoto and Sugane, 1995).

Furthermore, transgenic mice that constitutively express IL-5 in the lung epithelium develop an accumulation of eosinophils and pathologic changes including goblet cell hyperplasia, epithelial hypertrophy, and AHR even in the absence of antigen challenge (Lee et al., 1997).

\section{SIGNAL TRANSDUCTION THROUGH CHEMOKINE RECEPTORS}

Signal transduction initiated by chemoattractant receptors serves to generate distinct and/or amplified cellular responses (Simson and Foster, 2000). The ability of eosinophils to generate unique cellular responses lies in their activation of their receptor-mediated pathways. The GTPases, which belong to the Ras and Rho families, appear to play an important role at several critical checkpoints in eosinophil development and function (Hall, 1998; Henning and Cantrell, 1998; Muessel et al., 2008), including an integral role in shape, receptor aggregation, and cell migration.

Chemokines signal through $G$ protein-coupled receptors (GPCRs) on the eosinophil's surface. Three chemokine receptor subgroups are currently recognized - CCR, CXCR, and $\mathrm{CX}_{3} \mathrm{CR} 1-$ which recognize chemokines of the corresponding family. However, in most cases, chemokine receptors recognize more than one chemokine in that family and several chemokines bind to more than one receptor, although this ostensible promiscuity and redundancy may be limited by spatial and temporal regulation of these molecules (Baggiolini, 1998; Simson and Foster, 2000; Ono et al., 2003). In contrast to chemokine receptors, members of the cytokine receptor family consist of cell surface glycoproteins (Bagley et al., 1997; Simson and Foster, 2000; Le et al., 2004). These receptors display similar structural and functional properties. The receptors for IL-5, IL-3, and GM-CSF share structural similarities, although upon ligand binding the IL-5 and IL-3 receptors oligomerize while that of GM-CSF exists as a preformed complex (Simson and Foster, 2000; Ono et al., 2003).

Eosinophils express receptors for the CC chemokine family (Ponath et al., 1996; Borchers et al., 2002). Although many chemokines appear to be highly redundant and their receptors to be promiscuous, only three eosinophil chemotactic cytokines are known to interact with eosinophils. The eotaxins 1-3 signal on eosinophils through the seven-transmembrane receptor CCR3 (Conroy and Williams, 2001; Liu et al., 2006; Rosenberg et al., 2007). Eotaxin acts via the chemokine receptor CCR3 on eosinophils to stimulate the selective recruitment of these cells from the airway micro-vessels into the lung tissue (Pope et al., 2005). Animal models show a fundamental and synergistic role for IL-5 and eotaxin in the migration of eosinophils under basal conditions (Matthews et al., 1998), as well as during fungal allergy (Mould et al., 1997; Matthews et al., 1998; Schuh et al., 2002). Subcutaneous administration of IL-5 induces a concentration-dependent eosinophilia in mice (Palframan et al., 1998).

Eotaxin is expressed basally, but fungal challenge leads to an early increase in production and recruitment of eosinophils in allergic mice (Garcia-Zepeda et al., 1996; Lamkhioued et al., 1997; Matthews et al., 1998; Hoselton et al., 2010; Samarasinghe et al., $2010,2011 \mathrm{a}, \mathrm{b})$. The cytokines produced during the early phase response such as IFN- $\gamma$, TNF- $\alpha$, and IL- $1 \beta$ may regulate the production of eotaxin from endothelial cells which in turn promotes blood and tissue eosinophilia in the late phase response (Cook et al., 1998).

In addition to the eotaxins, eosinophil migration toward an increasing chemokine gradient may be elicited with other CC chemokines including CCL2/MCP-1 (monocyte chemotactic protein-1), CCL3/MIP-1 $\alpha$ (macrophage inflammatory protein$1 \alpha$ ), CCL5/RANTES (regulated upon activation, normal $\mathrm{T}$ cell expressed, and secreted), and CCL7/MCP-3. Although none of these is considered to be a specific eosinophil chemoattractant (Ponath et al., 1996; Schuh et al., 2003), each may play a role in the changing environment of the allergic lung as disease develops. Blockade of eotaxin using neutralizing antibodies (Abs) and single eotaxin-KO (Rothenberg et al., 1997) animals have revealed a significant, yet incomplete, reduction in eosinophilic inflammation (Rothenberg et al., 1997; Uhm et al., 2012). For example, the combined actions of the CC chemokines RANTES, MCP-1, and MCP-5, led to the development of OVA-induced lung eosinophilia (Gonzalo et al., 1998). Although it interacts non-specifically with eosinophils, neutralization of RANTES completely abolished OVA-induced lung eosinophilia (Gonzalo et al., 1998). Eosinophils express the chemokine receptor CCR1, which binds MIP-1 $\alpha$, RANTES, and MCP. There is an increase in the mRNA expression of MCP-1, RANTES, and MIP- $1 \alpha$ (Alam et al., 1996; Khalid et al., 2008) after allergen/fungal challenge and MIP$1 \alpha$ blockade has been shown to reduce lung eosinophils by $20 \%$ (Holgate et al., 1997; Gonzalo et al., 1998). In addition to CCR1 and CCR3, the CCL1/CCR8 axis has also been shown to preferentially induce the recruitment of eosinophils to the lung following allergen challenge (Lloyd and Rankin, 2003). These data demonstrate that CCR1 and other chemokine receptors may also be an important target in blocking eosinophil responses.

\section{IL-5/EOTAXIN SYNERGISM FOR CELL RECRUITMENT}

Eotaxin and IL-5 act co-operatively to regulate eosinophil homing and tissue accumulation (Collins et al., 1995; Choi et al., 2003). Murine studies using IL-5 KO mice have shown that subcutaneous administration of eotaxin alone is insufficient to induce 
tissue eosinophilia. Tissue eosinophilia could only be restored in these mice by administration of intravenous IL-5 for $72 \mathrm{~h}$ (Palframan et al., 1998). Other studies have shown that eotaxin plays an important role in initiating both blood and tissue eosinophilia in the early phase of allergic inflammation (Schuh et al., 2002), while IL-5 is essential for eotaxin-induced tissue eosinophilia (Collins et al., 1995; Rothenberg et al., 1996; Mould et al., 1997).

Following eotaxin activation, a series of events are triggered in the eosinophil, including calcium mobilization, CD11b upregulation, mitogen-activated protein kinase (MAP-kinase) activation, RhoA/ROCK pathway activation, reactive oxygen production, actin polymerization, and a rapid change in shape which is associated with cell migration/chemotaxis and/or granule release (Schmitz et al., 2000; Conroy and Williams, 2001; Sahai and Marshall, 2003; Paplinska et al., 2007; Muessel et al., 2008).

Incubating human eosinophils with IL-5 increases their migratory response to Platelet-activating factor (PAF), Leukotriene B4 (LTB4), Vasoactive intestinal peptide (VIP), and FormylMethionyl-Leucyl-Phenylalanine (FMLP), while having no effect on neutrophils (Numao and Agrawal, 1992; Sehmi et al., 1992; El-Shazly et al., 2000). Therefore, the presence of these mediators in the asthmatic lung may contribute to eosinophil migration in the presence of IL-5 (Trivedi and Lloyd, 2007) and these mediators have been shown to have stimulatory and chemoattractant properties.

\section{ADHESION MOLECULES}

Interleukin-5 and eotaxin cooperate to regulate eosinophil homing and tissue accumulation in allergic/fungal asthma by regulating adhesion pathways used by this leukocyte (Rothenberg et al., 1996; Schuh et al., 2002; Choi et al., 2003). Eosinophils express seven integrin heterodimers (Barthel et al., 2008): $\alpha 4 \beta 1$ (CD49d/29), $\alpha 6 \beta 1(\mathrm{CD} 49 \mathrm{f} / 29), \alpha \mathrm{M} \beta 2(\mathrm{CD} 11 \mathrm{~b} / 18), \alpha \mathrm{L} \beta 2$ (CD11a/18), $\alpha \mathrm{X} \beta 2$ (CD11c/18), $\alpha \mathrm{D} \beta 2(\mathrm{CD} 11 \mathrm{~d} / 18)$, and $\alpha 4 \beta 7$ (CD49d/ $\beta 7$; Georas et al., 1993; Grayson et al., 1998; Tachimoto and Bochner, 2000). Each set of heterodimers interacts with its own ligand which is deposited in ECM or a counter-receptor on another cell. Understanding the function of integrin receptors on a given cell type is complicated by the fact that each integrin may be present in different conformational states, and may have varying levels of expression and clustering on the cell surface (Humphries, 2004; Xiao et al., 2004; Hogg et al., 2011; Long, 2011; Vestweber, 2012). Therefore, the migration of eosinophils to the allergic lung involves a complex interplay of integrin receptors in different states of activation, interacting with a diverse set of ligands on bronchial endothelium and cells within the tissue. The adhesion molecules, particularly the $\alpha_{4} \beta_{1}$ integrin very late antigen (VLA)-4, a ligand for the integrin vascular cell adhesion molecule (VCAM)-1, $\alpha_{A} \beta_{2}$ for ICAM-1, and the P-selectin glycoprotein ligand (PSGL)-1 ligand for P-selectin mediate the migration of eosniophils across epithelial and endothelial barriers (Rosenberg et al., 2007). Eotaxin-1 plays a role in regulating the expression of VLA-4 on eosinophils (Jia et al., 1999; Sung et al., 2000) and studies performed with anti-integrins and blocking Abs for VLA-4 on mice subjected to allergen challenge suggest that this ligand is a crucial component of the eosinophil inflammatory response (Gascoigne et al., 2003; Koo et al., 2003). Because the VLA-4/VCAM-1 interaction promotes the specific adhesion of eosinophils and not neutrophils, several small molecule inhibitors of the VLA4/VCAM-1 interaction are under exploration as asthma therapeutics (Hagmann, 2004; Okigami et al., 2007). In addition to IL-5 and eotaxin, GM-CSF has also been shown to promote eosinophil migration. Integrins $\alpha \mathrm{M} \beta 2$ (Mac-1/CD11b) or $\beta 2$ (CD18) have been shown to play a role in GM-CSF induced eosinophil migration (Muessel et al., 2008). Furthermore, recent studies have shown that in atopic patients there is an increase in the expression of 2B4 (CD244; Munitz et al., 2005; El-Shazly et al., 2011) and CD48 (Munitz et al., 2006) on eosinophils indicating a broader role of these receptors on human eosinophils. Future studies that may involve elucidating the role of these receptors in promoting inflammation in fungal allergy would be of great interest.

Studies using ragweed pollen in both P-selectin- and ICAMdeficient mice have shown a decrease in pulmonary eosinophilia when compared to wild type controls, although eosinophil recruitment was not completely abolished in P-selectin/ICAM-1 double KO mice (Broide et al., 1998). Complete abrogation of eosinophilia was observed in ICAM-1/VCAM-1 double KO mice after allergen challenge (Gonzalo et al., 1996), demonstrating the direct regulation of endothelial-eosinophil interactions governing eosinophilia (Gonzalo et al., 1996).

\section{COMPLEMENT PROTEINS, EXTRACELLULAR MATRIX COMPONENTS, NEUROPEPTIDES, AND OTHER MOLECULES}

Platelet-activating factor, VIP, and secretin are capable of inducing chemotaxis of human eosinophils (El-Shazly et al., 1996, 2000; Schweizer et al., 1996; Dunzendorfer et al., 1998). Other eosinophil chemoattractants include lipid mediators such as cysteinyl leukotrienes $\left(\mathrm{LTB}_{4}\right.$ and $\left.\mathrm{LTE}_{4}\right)$, bacterial-derived peptide fMLP, and the complement anaphylatoxins C3a and C5a (Rot et al., 1992; Dahinden et al., 1994; Simson and Foster, 2000; Kato et al., 2004).

Complement anaphylatoxins C3a and C5a induce eosinophil migration and extravasation into tissues in allergic/fungal asthma (Humbles et al., 2000; Baelder et al., 2005; Guo and Ward, 2005; Discipio and Schraufstatter, 2007). Although C3a and C5a influence many cell types, they are most well recognized as mediators of leukocyte activation (Hugli, 1986; Jagels et al., 2000). Eosinophils express both $\mathrm{C} 3 \mathrm{a}$ and $\mathrm{C} 5 \mathrm{a}$ receptors. C3a is highly selective for eosinophil migration, while C5a shows a broader range of cellular actions with an even more potent activation of eosinophil recruitment (Daffern et al., 1995; Discipio et al., 1999). Receptors for C3a and C5a belong to the GPCR family that is characterized by a seven-membrane spanning polypeptide chain, which is functionally associated with a pertussis toxin-sensitive $G$ protein. In granulocytes, this is Goi (Norgauer et al., 1993; Ames et al., 1996; Roglic et al., 1996; Guo and Ward, 2005). C5a initiates a complex cell signaling system in eosinophils through tyrosine kinase activation of phosphatidylinositol 3 kinase, which induces changes in cellular morphology that are necessary for the cell to migrate along a chemotactic or haptotactic gradient (Norgauer et al., 1993; Ames et al., 1996; Jagels et al., 2000).

Eosinophils survive in the tissues due to an autoregulatory production of GM-CSF as a result of the adhesion of $\alpha 4$ to fibronectin in the extracellular tissue matrix (Mishra et al., 1999). 
Recent studies by Ohkawara et al. (2000) have shown a role of the glycosaminoglycan hyaluronic acid, which is also a component of the ECM in the activation and survival of eosinophils. Further studies on the role of ECM components in eosinophil migration, chemotaxis, and function in fungal asthma would have important implications for understanding their role in eosinophil activation in health and disease.

In the past decade or so, intensive work in the fields of neuropeptides and immune cells has resulted in accumulating evidence that supports the existence of a neuroimmune axis (Numao and Agrawal, 1992; El-Shazly et al., 2000). Neuropeptides, such as VIP and secretin, are capable of inducing chemotaxis of human eosinophils (Schweizer et al., 1996; Dunzendorfer et al., 1998; ElShazly et al., 2000). Furthermore, VIP has been shown to induce eosinophil derived neurotoxin (EDN) release in a potency comparable to that induced by platelet-activating factor (El-Shazly et al., 2000). Studies using an A. fumigatus inhalational allergic model system have shown that the VIP signaling through its VPAC2 receptor dysregulates or causes significant temporal delays of immune cell recruitment and Th2 polarization (Hoselton et al., 2010; Samarasinghe et al., 2010). In vivo experiments using VPAC2-deficient mice in an allergic fungal model have supported the proposition that the Th2 phenotype is induced by VPAC2 signaling, as mice deficient for VPAC2 showed a 75\% reduction in the recruitment of eosinophils to the airway lumen (Samarasinghe et al., 2010, 2011a). Further studies to elucidate the mechanism of eosinophil migration using an autocrine VIP/VPAC2 signaling loop and its effect on chemotaxis would be of great interest.

A similar observation with VIP and eosinophil migration has been reported recently in an allergic rhinitis model (El-Shazly et al., 2013). Eosinophils infiltrated in the allergic nasal tissue have been shown to express high levels of VIP. Furthermore, eosinophil treatment with VIP has been reported to up-regulate the expression of CRTH2 (CD294) on human eosinophils and total CRTH2 protein (El-Shazly et al., 2013). This phenomena was shown to be independent of VPAC1 and VPAC2 suggesting a possible role of CRTH2 in eosinophil migration. However, the role of this receptor in eosinophil migration in the context of fungal allergy remains to be elucidated.

\section{FUNGUS-ASSOCIATED PULMONARY ALLERGY AND PATHOLOGY \\ DEVELOPMENT OF ALLERGIC FUNGAL RESPIRATORY DISEASE}

Allergic fungal asthma is a chronic disease that is important from both a personal and public perspective. AHR, inflammatory infiltrates, smooth muscle increases, and fibrotic remodeling of the bronchial architecture are features of allergic fungal asthma. Sensitization and colonization by fungal species often results in chronic architectural changes in the lung, causing long-term morbidity (Denning et al., 2006; Knutsen and Slavin, 2011), reduced productivity and quality of life, as well as increased costs associated with medical treatment. Epidemiological studies in the U.S. and Europe have associated mold sensitivity to Alternaria alternate and Cladosporium herbarum with the development, persistence, and severity of asthma (Knutsen et al., 2012). In addition, sensitivity to A. fumigatus has been associated with severe persistent asthma in adults (Knutsen et al., 2012). Severe asthma with fungal sensitization (SAFS) is a new designation in pulmonary diagnostics and treatment (Denning et al., 2006) and experimental models using A. fumigatus are being used to explore the course and mechanisms at play in fungal interactions.

The majority of fungal spores counted from outdoor air samples are from the phyla Ascomycota or Basidiomycota (Horner et al., 1995). The most commonly studied fungal allergens are Aspergillus, Alternaria, Botrytis, Cladosporium, Epicoccum, Fusarium, and Penicillium species (Knutsen et al., 2012). In a recent study, over $40 \%$ of children who had failed combination therapy with high dose inhaled corticosteroids and long-acting beta agonists were diagnosed with SAFS (Vicencio et al., 2012). In this study, many children (65\%) displayed antibody specificity to more than one fungal species, with Aspergillus (81.2\%) and Alternaria $(68.8 \%)$ species being the most commonly associated with sensitivity (Vicencio et al., 2012). Conidia (spores) are present in the outdoor environment throughout the year in many environments and frequently exceed the pollen population by 100 - to 1000 fold (Knutsen et al., 2012). Spores and fungal fragments found in indoor environments originate from fungi present outdoors and from fungi that grow in moist indoor environments such as damp basements (Aukrust, 1979).

Aspergillus fumigatus is distributed widely in the environment. It is a saprophytic mold with an important environmental function in carbon and nitrogen cycling (Dagenais and Keller, 2009). As an opportunistic pathogen of plants and animals as well as a prominent sensitizing agent in allergic respiratory diseases, $A$. fumigatus is among the most well recognized and best studied fungal species of the total estimated 3.5-5.1 million that are predicted from high throughput environmental screening (O'Brien et al., 2005). Its hydrophobic spores are readily dispersed in the environment and, when inhaled, are small enough to navigate the airways of the lung far beyond the barriers of the ciliated epithelium (Latge, 1999). The growth habit and physical characteristics of A. fumigatus make it an opportunistic pathogen of humans and an ideal carrier of aeroallergens. Cellular innate (neutrophil- and macrophage-mediated) and adaptive (Th1-mediated) immune responses protect against infection by Aspergillus in a normal lung (Grazziutti et al., 1997; Traynor and Huffnagle, 2001; Beck et al., 2006; Murdock et al., 2011), but A. fumigatus can also induce or exacerbate allergies of the upper and lower airways, and exposure to Aspergillus can result in invasive aspergillosis (IA) in immunocompromised patients.

Sensitization to fungal species arises from a combination of genetic and environmental factors, along with certain characteristics of the allergen itself. Both indoor and outdoor environmental exposure has been associated with asthma exacerbations (Pongracic et al., 2010). Some studies have demonstrated a correlation between visible mold growth in homes and asthma episodes in children (Bundy et al., 2009; Karvonen et al., 2009). Both allergic rhinitis and asthma have been associated with exposure to fungal contamination in homes (Park et al., 2008). A recent study involving a quantitative meta-analysis of 33 epidemiological studies has shown an increase of $30-50 \%$ in adverse respiratory health outcomes in occupants because of dampness and mold exposure (Fisk et al., 2007). Furthermore, recent reviews from the United States, Europe, and the World Health Organization affirm that a damp 
indoor environment is a factor in asthma development (Mendell et al., 2011).

Aspergillus-induced asthma is characterized by increases in mature eosinophils and their progenitors within the bone marrow, blood, and bronchi. In asthmatic patients, eosinophils generate a variety of pro-inflammatory mediators that can disrupt epithelial integrity and inflict damage to the ECM. In addition, they stimulate the degranulation of mast cells and basophils (Reed, 1994; Makino and Fukuda, 1995; Pearlman, 1999; Hogaboam et al., 2003; Clark et al., 2004; Williams, 2004; Kariyawasam and Robinson, 2007; Hoselton et al., 2010; Venge, 2010; Samarasinghe et al., 2011a,b). For these reasons, eosinophils represent potential effector cells in the pathogenesis of allergic fungal asthma.

\section{PATHOLOGY OF FUNGAL ALLERGIC ASTHMA}

Sensitization to Aspergillus is common in atopic individuals and $A$. fumigatus is responsible for approximately 16-38\% of Aspergillusrelated illness in humans (Schwartz et al., 1978; Maurya et al., 2005). In asthmatic individuals, Aspergillus sensitization, or allergic bronchopulmonary aspergillosis (ABPA), is characterized by exacerbations of asthma, recurrent transient chest radiographic infiltrates, expectoration of thick mucus plugs, blood and pulmonary eosinophilia, and increased total serum and fungusspecific IgE levels. ABPA is the most common form of allergic bronchopulmonary mycosis (ABPM) although other fungi, including Candida, Penicillium, and Curvularia species, are also implicated. Balls of fungus called aspergillomas may form following repeated exposure to conidia and target preexisting lung cavities such as the healed lesions in tuberculosis patients. IA is the most devastating of the Aspergillus-related diseases, targeting severely immunocompromised patients (Dagenais and Keller, 2009). In immunocompromised patients or those with previous lung damage, A. fumigatus can germinate and its growth may invade local blood vessels causing disseminated fungal disease with mortality rates ranging from 40 to $90 \%$ (Lin et al., 2001; Dagenais and Keller, 2009).

Some of the symptoms of fungal asthma are familiar: sneezing, coughing, mucus production, AHR. Although the chronic changes in the structure of the airway wall are less obvious, they represent an accumulated dysfunction that can significantly impact a patient's quality of life (Lacoste et al., 1993; Jeffery, 2001; Agrawal and Shao, 2010; Bellido-Casado et al., 2010; Hoselton et al., 2010). As inflammation plays an important role in most of the symptoms that are associated with fungal asthma, much attention has been focused on delineating the mechanisms of development and persistence of inflammation. Repeated exposure to allergens like A. fumigatus results in the accumulation of neutrophils, basophils, and mast cells which are characteristic features associated with the early phase inflammatory reaction (Galli, 2000; Hogaboam et al., 2003; Bosiger and Fehr, 2006; Verstraelen et al., 2008; Hoselton et al., 2010; Amin, 2012), while the late phase reaction is characterized by the accumulation of Th2 lymphocytes (Horwitz and Busse, 1995), B lymphocytes (Horwitz and Busse, 1995; Ghosh et al., 2012), neutrophils (Horwitz and Busse, 1995; Hogaboam et al., 2003), macrophages (Horwitz and Busse, 1995; Hogaboam et al., 2003; Samarasinghe et al., 2011b), basophils (Horwitz and Busse, 1995; Smit and Lukacs, 2006), and eosinophils (Smit and Lukacs, 2006; Campos and Pereira, 2009; Samarasinghe et al., 2011b) in the airway tissue, including the sub-mucosa, epithelium, and airway lumen (Horwitz and Busse, 1995; Hogaboam et al., 2003; Smit and Lukacs, 2006; Verstraelen et al., 2008; Campos and Pereira, 2009; Fahy, 2009; Hamid and Tulic, 2009; Hoselton et al., 2010; Samarasinghe et al., 2011a,b; Ghosh et al., 2012).

\section{EOSINOPHIL-ASSOCIATED DAMAGE IN ALLERGIC ASTHMA}

Eosinophils have a central role in the inflammatory milieu that is established within the asthmatic lung, and primed eosinophils can be further activated by numerous stimuli including GM-CSF, IL-5, and Abs (Capron et al., 1989; Kotsimbos and Hamid, 1997; Adachi and Alam, 1998; Flood-Page et al., 2003; Bartemes et al., 2005). GM-CSF activates and enhances eosinophil functions, such as superoxide production, leukotriene production, phagocytosis of serum opsonized zymosan, and Ig-induced degranulation (Kita, 2011). IL-5, apart from increasing the chemotactic response of eosinophils, also plays a role in superoxide generation, phagocytosis, and immunoglobulin-induced degranulation (Kita et al., 1992).

Eosinophils can also recognize the products of adaptive immunity. Sepharose beads coated with IgG, IgA, and secretory IgA (sIgA) have been shown to stimulate eosinophil degranulation, and sIgA was the most effective among these Igs. The exact mechanism to explain why sIgA is more potent is unknown but eosinophils possess binding sites for the secretory component. Furthermore, interaction with sIgA increases eosinophil pro-inflammatory function (Abu-Ghazaleh et al., 1989; Monteiro et al., 1993; Motegi and Kita, 1998). The role of IgE, which is a hallmark of allergic disease, in mediating eosinophil activation is controversial. Some studies have shown that eosinophils isolated from patients with eosinophilia degranulate in response to antiIgE antibody (Moqbel et al., 1990) and that a high-affinity IgE receptor is present on eosinophils from patients with eosinophilia and various effector functions are mediated through this receptor (Moqbel et al., 1990; Gounni et al., 1994). Other studies have shown that the number of high-affinity receptors expressed on the surfaces of eosinophils from patients with allergic diseases was minimal and that ligation of FcERI does not result in eosinophil degranulation (Kita et al., 1999; Seminario et al., 1999). However, the role of high-affinity receptors in mouse models of fungal asthma are still unclear.

Eosinophils are able to release stored mediators via three highly regulated degranulation mechanisms, classical exocytosis, compound exocytosis, and piecemeal degranulation. Degranulation can also occur by cytolysis where the entire contents of the cell are released during rupture (Logan et al., 2003). Classical exocytosis involves the extrusion of single secretory granules but has not been demonstrated in airway tissue (Erjefalt and Persson, 2000). Compound exocytosis involves the fusion of multiple intracellular granules followed by a focused secretion onto the target cell at the site of adhesion (Hafez et al., 2003); while piecemeal degranulation allows the partial and selective release of granule contents by transferring them into small vesicles that are subsequently released by exocytosis. This is demonstrated by the selective release of RANTES from IFN- $\gamma$ stimulated human eosinophils 
independently of both major basic protein (MBP) and eosinophil peroxidase (EPO) release (Lacy et al., 1999).

The cytotoxic compounds contained in the granules of eosinophils are capable of killing filarial stages. The eosinophil's anti-helminthic functions have been recognized since the mid1970s (Butterworth et al., 1975). The same granules were recognized to be cytotoxic to bronchial epithelium, as well, and have for some time been firmly associated with the immunopathology of allergic asthma (Butterworth et al., 1975). In addition, release of eosinophilic granules increases vascular permeability in vivo at physiologic concentrations that are observed in pathological conditions associated with allergic/fungal asthma (Piliponsky et al., 2002; Bloemen et al., 2007). They also activate mast cell release of pro-inflammatory mediators including histamine, eicosanoids, and cytokines (Minnicozzi et al., 1994; Bloemen et al., 2007). Eosinophils produce stem cell factor (SCF) and nerve growth factor (NGF), which further support the growth and survival of mast cells (Piliponsky et al., 2002). Eosinophils also produce the Th2-type cytokines IL-4 and IL-13, which potently stimulate the release of eotaxin and the production of RANTES and MCP1, further enhancing eosinophil recruitment. Eotaxin can induce respiratory burst and actin polymerization in eosinophils, directly contributing to tissue damage as well as orchestrating the continual recruitment of both eosinophils and T cells (Li et al., 1999). A summary of different mediators released by eosinophils in the allergic lung is delineated in Table 2 .

Airway hyperresponsiveness refers to the increased ability of the airways to narrow after exposure to non-specific stimuli. It is a

Table 2 | Mediators released by eosinophils.

\begin{tabular}{|c|c|c|c|}
\hline & Mediator & General function & Reference \\
\hline \multirow{16}{*}{$\begin{array}{l}\text { Basic granule } \\
\text { proteins }\end{array}$} & Major basic protein (MBP) & Respiratory epithelial desquamation & Frigas et al. (1981) and Gleich (2000) \\
\hline & & M2 receptor dysfunction & Fryer and Jacoby (1998) and Takafuji et al. (1998) \\
\hline & & Mammalian cell and parasite toxicity & O’Donnell et al. (1983) and Piliponsky et al. (2002) \\
\hline & & Stimulation of neutrophils, & Gleich (2000) \\
\hline & & Mast cells, and basophils & Jacoby et al. (1993) \\
\hline & Eosinophil cationic protein (ECP) & Bronchial Hyperresponsiveness & Gleich (2000) and Weller (2008) \\
\hline & & Leads to bronchoconstriction & Rosenberg et al. (1989) and Weller (2008) \\
\hline & & Respiratory epithelial desquamation & Gleich (2000) \\
\hline & & Cell and parasite toxicity & Zheutlin et al. (1984) \\
\hline & & Generation of radical species & Kay (1988) and Gleich (2000) \\
\hline & & Stimulation of mast cells & Wu et al. (1999) and Matsunaga et al. (2000) \\
\hline & Eosinophil peroxidase (EPO) & Suppression of lymphocyte response & Takafuji et al. (1998) and Gleich (2000) \\
\hline & & Mast cell and basophil degranulation & Ayars et al. (1989) and Fryer and Jacoby (1998) \\
\hline & & M2 receptor dysfunction & Wu et al. (1999) and Gleich (2000) \\
\hline & & Cell and parasite toxicity & Wardlaw et al. (2000) \\
\hline & & Generation of oxygen radicals & Wu et al. (1999) \\
\hline \multirow[t]{4}{*}{ Chemokines } & $\begin{array}{l}\text { CCL2, CCL3, CCL11, CCL5 and } \\
\text { IL-8 }\end{array}$ & $\begin{array}{l}\text { Migration of monocytes, macrophages, } \\
\text { neutrophils, T cells, and eosinophils }\end{array}$ & $\begin{array}{l}\text { Yousefi et al. (1995), Ying et al. (1996), and Nakajima } \\
\text { et al. (1998) }\end{array}$ \\
\hline & & Increased eosinophil survival & Gleich (2000) \\
\hline & & Increased adhesion molecules expression & Weller (2008) \\
\hline & & Airway wall remodeling & Elsner and Kapp (1999) \\
\hline \multirow[t]{5}{*}{ Cytokines } & $\begin{array}{l}\text { IL-3, IL-5, IL-9, GM-CSF, IFN- } \gamma \text {, } \\
\text { TNF- } \alpha \text {, and IL-2 }\end{array}$ & Sustained inflammation & Elsner and Kapp (1999) \\
\hline & $\begin{array}{l}\text { IL-6, IL-4, IL-13, IL-16, IL-17, IL-2, } \\
\text { and IL-8 }\end{array}$ & $\begin{array}{l}\text { Eosinophil migration, development, and } \\
\text { survival }\end{array}$ & Sanderson (1992) and Weller (2008) \\
\hline & & Increased adhesion molecule expression & Arm and Lee (1992) and Sanmugalingham et al. (2000) \\
\hline & & Airway wall remodeling & Nonaka et al. (1995) and Woerly et al. (2002) \\
\hline & & & Rand et al. (1991) and Minshall et al. (2000) \\
\hline \multirow[t]{6}{*}{ Lipids } & Cysteinyl leukotrienes, PAF, & Increased mucus secretion & Kupczyk and Kuna (1999) and Weller (2008) \\
\hline & $\mathrm{PGD}_{2}$, and $P G E_{2}$ & Increased vascular permeability & Kupczyk and Kuna (1999) and Gleich (2000) \\
\hline & & $\begin{array}{l}\text { Activation of eosinophils, mast cells, } \\
\text { basophils, neutrophils, and platelets }\end{array}$ & Kupczyk and Kuna (1999) and Gleich (2000) \\
\hline & & Smooth muscle cell contraction & Kupczyk and Kuna (1999) and Gleich (2000) \\
\hline & & Increased adhesion molecules expression & Kupczyk and Kuna (1999) and Gleich (2000) \\
\hline & & Chemotaxis of eosinophil and neutrophil & Kupczyk and Kuna (1999) and Weller (2008) \\
\hline
\end{tabular}


classical feature of Aspergillus-induced allergic asthma, and AHR severity correlates with the severity of the disease (Hogaboam et al., 2003; Boutet et al., 2007; Dagenais and Keller, 2009; Ramaprakash et al., 2009; Samarasinghe et al., 2010, 2011a,b). Similarly, eosinophilic inflammation is the characteristic feature associated with allergic asthma and it broadly correlates with disease severity (Hogaboam et al., 2003; Boutet et al., 2007; Dagenais and Keller, 2009; Ramaprakash et al., 2009; Samarasinghe et al., 2010, 2011a,b). Eosinophils that are recruited and activated after allergen challenge are believed to contribute to AHR by the direct release of pro-inflammatory mediators and by interaction with other cell types. In addition, eosinophils indirectly contribute to the development of AHR by the induction of mast cell and basophil degranulation, leading to the local release of prostaglandins, leukotrienes, and histamines, all of which can induce AHR (Kay, 1983). Many studies support this long-standing view of the eosinophils as a central effector in allergic airway disease. In C57BL/6J murine model of allergic asthma, thorough depletion of eosinophils using an antibody against CCR3 results in a down regulation of AHR with observed changes in the number of other cell types (Justice et al., 2003).

The impact of eosinophils on the activation of Th2 cells is another way that they contribute to the ongoing allergic lung response. While the Th2-type cytokine IL-13 can induce AHR independently of eosinophilia (Grunig et al., 1998), ablation of eosinophils in a IL-5/eotaxin double knockout system abolishes AHR by reducing the ability of T cells to produce IL-13 (Mattes et al., 2002).

Airway remodeling refers to structural changes in the asthmatic airways which occur as a result of dysfunctional repair processes within the lung. It is characterized by the increased deposition of ECM proteins such as collagen I and tenascin within the reticular basement membrane and bronchial mucosa, increases in airway smooth muscle mass, and goblet cell hypertrophy and hyperplasia (Samarasinghe et al., 2010, 2011a,b; Girodet et al., 2011). Airway remodeling may contribute to AHR and fixed airway flow obstruction and also contribute to the loss of lung function over time (Kariyawasam and Robinson, 2005).

Eosinophils release a number of mediators that have been associated with airway remodeling. The essential role of eosinophils in airway remodeling was first described by a study in which eosinophils were genetically ablated in mice by the deletion of the high-affinity GATA-binding site in the GATA-1 promoter (McMillan and Lloyd, 2004). After a period of prolonged allergen challenge, wild type mice exhibited the prominent features of airway remodeling, namely increased sub-epithelial deposition of collagen together with airway smooth muscle cell hypertrophy and proliferation, but these features were abrogated in double knockout GATA mice (Humbles et al., 2004).

Eosinophils additionally contribute to airway remodeling and fibrosis in allergic/fungal asthma by synthesizing a number of profibrotic mediators. Eosinophils are thought to be an important source of the pro-fibrotic cytokine TGF- $\beta$ (Minshall et al., 1997; Ohkawara et al., 2000; Cho et al., 2004; Rosenberg et al., 2013). Studies have shown that eosinophils release TGF- $\beta$ in response to low molecular mass HA and that IL- 4 and IL- 5 can stimulate eosinophils to release TGF- $\beta$ in vitro (Elovic et al., 1998; Ohkawara et al., 2000). However, other cell types also have the capability to produce TGF- $\beta$ (Boxall et al., 2006). TGF- $\beta$ is able to induce ECM protein production, and also contributes to the accumulation of fibroblasts below the reticular basement membrane by stimulating fibroblast proliferation (Fine and Goldstein, 1993; Richter et al., 2001; Kenyon et al., 2003; Doherty and Broide, 2007). Eosinophils also promote the differentiation of myofibroblasts from resident fibroblasts (Masur et al., 1996) and also from circulating precursor cells known as fibrocytes (Mori et al., 2005). In addition, the differentiation of myofibroblasts into smooth muscle cells and their proliferation may also be governed by TGF- $\beta$ (Wicks et al., 2006). IL-5 KO mice have significantly reduced BAL eosinophils and airway remodeling in a model of chronic allergen challenge (Cho et al., 2004; Tanaka et al., 2004). Both studies show a role of eosinophil derived TGF- $\beta$ in the propagation of airway remodeling. Furthermore, administration of an anti-TGF- $\beta$ antibody in sensitized mice followed by allergen challenge prevented the progression of airway remodeling without altering inflammation (McMillan et al., 2005). Treatment of asthmatic patients with an anti-IL-5 antibody reduces the deposition of ECM proteins within the lung with a reduction in BAL TGF- $\beta$ (Flood-Page et al., 2003). However, the precise role of TGF- $\beta$ derived from eosinophils is complicated by the fact that the TGF- $\beta$ may induce the expression of other fibrotic factors such as plasminogen activator inhibitor while being able to act in an either synergistic or antagonistic manner with other factors such as epidermal growth factor (Hara et al., 2001). A summary of eosinophil function in the allergic lung is shown in Figure 2.

\section{EFFECT OF ANTI-EOSINOPHIL TREATMENTS}

The fact that a number of chemotherapeutic agents that are effective in alleviating asthma symptoms reduce tissue eosinophilia in allergic asthma has cemented the role of eosinophils as immunopathologic in the minds of many scientists and clinicians. Glucocorticoids induce a marked eosinopenia when given orally, and both oral and inhaled glucocorticoids reduce tissue eosinophilia (Wardlaw et al., 2000). Oral prednisolone has been shown to cause an amelioration of sputum eosinophilia and ECP level in patients with severe disease exacerbations, which correlates with improvement in lung function (Claman et al., 1994). Leukotriene antagonists modestly reduce eosinophilia in the allergic lung (Rothenberg and Hogan, 2006). In addition, cyclosporin and a thromboxane $\mathrm{A}_{2}$ antagonist reduce the eosinophil count in asthmatic airways although is not clear if their effect on eosinophils is a major role as they have a wide range of other actions in asthma (Claman et al., 1994; Hoshino et al., 1999; Khan et al., 2000). Omalizumab, a humanized monoclonal antibody which binds to free $\mathrm{IgE}$, has been shown to block the release of inflammatory mediators from mast cells and reduces the infiltration of inflammatory cells, notably eosinophils (Sarinho and Cruz, 2006).

Given the central role of IL-5 in eosinophil development and action, a number of studies have focused on blocking IL-5 and its effect on eosinophilia and the symptoms associated with allergic asthma. Clinical trials have targeted IL-5 using 2 humanized monoclonal Abs, SCH55700 (Schering-Plough Research Institute, Kenilworth, NJ, USA) and mepolizumab (GlaxoSmithKline, Middlesex, UK; O'Byrne et al., 2001; Kay and Klion, 2004). In a 


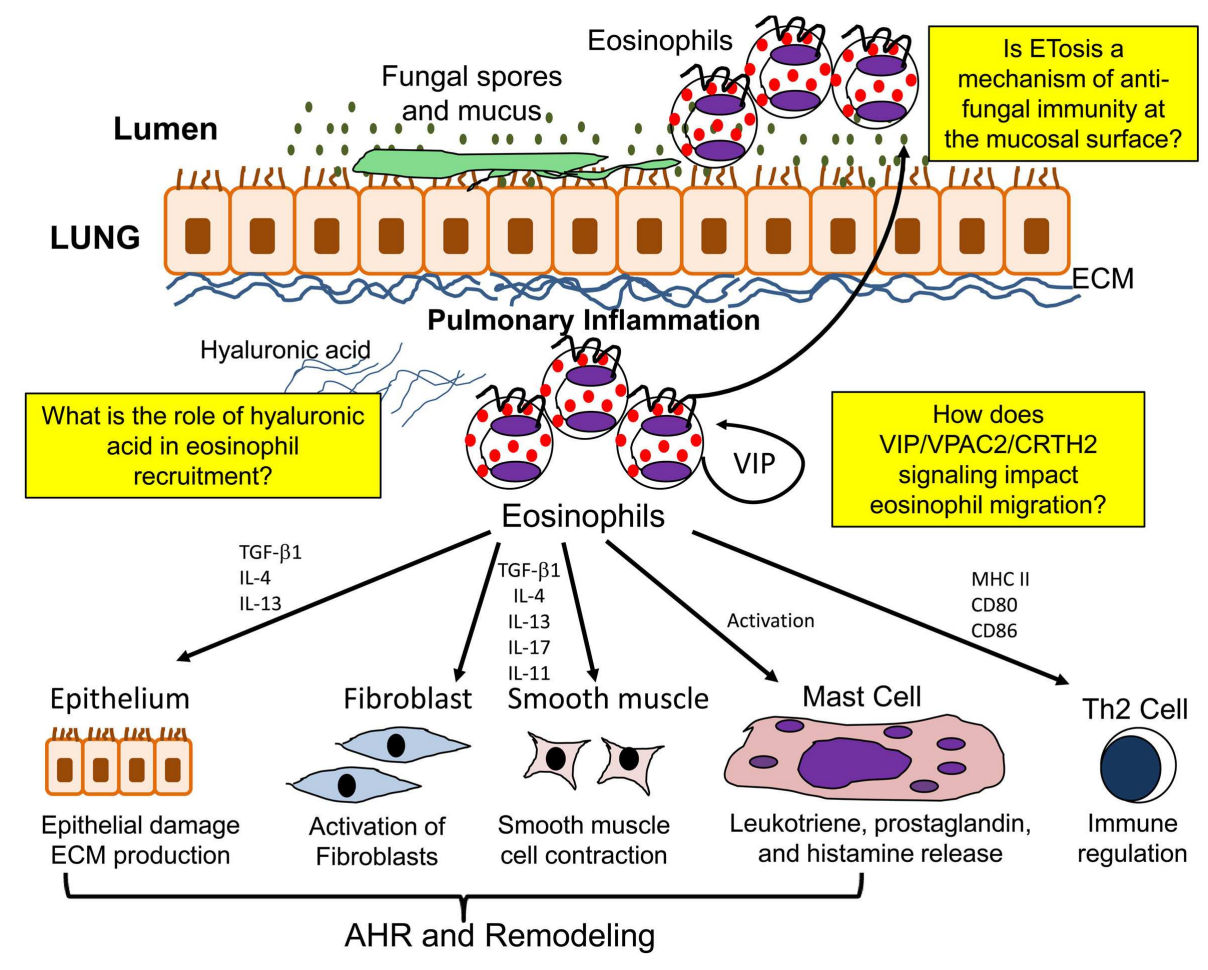

FIGURE 2 | Function of eosinophils in the allergic lung. In the allergic lung eosinophils are activated to release a number of mediators which may contribute to airway hyperresponsiveness (AHR), airway remodeling, immunomodulation, and ETosis.

randomized, double-blind study of mepolizumab, clinical symptoms of patients with asthma were unaffected despite a dramatic decline in peripheral blood eosinophilia. Most interestingly, despite repeated administration of anti-IL-5 therapy, eosinophils persisted in the lung tissue and in the airway (Kay and Klion, 2004). An independent trial performed with SCH55700 resulted in a similar depletion of peripheral blood eosinophils without improvement in clinical symptoms. These results may be related to complexities of specific disease states (O'Byrne et al., 2001).

Eosinophils have long been reported to produce the cytokine TGF- $\beta$ in allergic asthma (Leavy, 2008). TGF- $\beta$ is one of the main effectors involved in tissue remodeling in the asthmatic lung and is overexpressed in the allergic lung (Kay et al., 2004; Leavy, 2008). Potential therapeutic applications that modulate the TGF- $\beta$ response in fungal asthma may help to elucidate the role of both TGF- $\beta$ and eosinophils in allergic asthma.

\section{MECHANISMS OF EOSINOPHIL-MEDIATED IMMUNITY}

In the context of an allergic respiratory response to an inert agent like pollen, animal dander, or house dust mite, eosinophils have an entrenched identity as instigators and perpetuators of an immunopathologic inflammatory response (Tenscher et al., 1996). Interestingly, recent information examining the conservation of allergen sequence homology across helminth, protozoan, and fungal organismal databases show that minor allergens generally have common homologs among these groups and also may have homologs in common with bacterial or human proteins. However, major allergens - defined as a specific substance that elicits an IgE response in at least $50 \%$ of the individuals who are allergic to the complex mixture in which the substance is found - are often unique to the individual helminth, protozoan, or fungal group (Santiago et al., 2012). If, then, allergy is not merely a vestige of cross-reactivity among classes of pathogens or host proteins, what is its role in the adaptive immune response to helminths, protozoans, and/or fungi?

Let us look at the role of the eosinophil, not from an immunopathologic perspective, but from that of an immune effector cell. Eosinophilia is a characteristic of many allergic diseases, and the accumulation and degranulation of these cells in a tissue may contribute to epithelial sloughing. The epithelium turns over quickly in an atopic lung. Murine models of fungal allergic asthma show a marked and dynamic metaplasic phenotype in which nearly $100 \%$ of the lining of the large airways is not ciliated columnar cells, but mucus-producing, non-ciliated goblet cells. In an overwhelming inhalation of fungal spores when the innate mechanisms that typically phagocytose and eliminate fungal spores from the airways become inundated, a mechanism by which the columnar epithelium is replaced by sticky, mucus-producing cells may make the most sense.

Recent work shows an important antifungal role for these granulocytes in the context of the pulmonary lumen. Eosinophils have been reported to exert a strong inflammatory response against germinating A. alternata resulting in killing of the fungus (Yoon et al., 2008). This phenomena was shown to be mediated by a $\beta-2$ integrin adhesion molecule, CD11b which is present on eosinophils and can interact with $\beta$-glucan present on the surface 
of $A$. alternata (Yoon et al., 2008) further suggesting an important antifungal role of these granulocytes.

Eosinophils, frequently associated with chronic allergic conditions and asthma, have molecular receptors that have been implicated in the recognition of A. fumigatus components. Targeting eosinophils has proven effective at ameliorating symptoms in patients with severe asthma (Haldar et al., 2009). $\beta$ D-glucan, a major component of the fungal cell wall, has been associated with an increased peak expiratory flow variability in children with asthma (Douwes et al., 2000). Dectin-1, which is a receptor for $\beta$-D-glucan is present on macrophages, neutrophils, and dendritic cells and it transduces signals to various cell responses with phagocytosis, oxidative burst, and production of inflammatory mediators, including IL-8, IL-6, IL12, IL-18, and TNF- $\alpha$ (Hohl, 2008; Goodridge et al., 2009). Recent studies report the presence of dectin-1 on human eosinophils, indicating that fungal components can directly activate eosinophils (Goodridge et al., 2009; Kvarnhammar and Cardell, 2012).

Chitin is another component of the fungal cell wall and has been identified as a recognition element capable of initiating immune responses associated with allergy and asthma (Chatterjee et al., 2008; Van Dyken et al., 2011). Increased chitinase levels have been associated with asthma and increased IgE levels (Chatterjee et al., 2008). Furthermore, eosinophils are recruited in response to chitin by a mechanism dependent on the high-affinity LTB4 receptor (Reese et al., 2007). In summary, all the above mentioned studies suggest an important immune effector function of eosinophils in the context of allergic disease.

\section{IMMUNOMODULATION}

The recognition of eosinophils as complex immunomodulatory cells has been increasing in recent years. One novel immunomodulatory function of eosinophils is that they can act as antigen presenting cells (APCs) as they express MHC Class II (Koeffler et al., 1980; Lucey et al., 1989). In vitro, the expression of MHC Class II is dependent on stimulation of eosinophils by GM-CSF (Lucey et al., 1989). More immediately relevant to in vivo disease are a series of observations that eosinophils recovered from sites of allergic or parasitic inflammation expressed MHC Class II (Hansel et al., 1991; Sedgwick et al., 1992; Mawhorter et al., 1993). In patients with asthma, eosinophils isolated from sputum expressed the MHC Class II protein HLA-DR. In mouse models of parasitic infection, MHC Class II was upregulated in eosinophils recovered from sites on infection (Mawhorter et al., 1993). MHC Class II alone, however, is insufficient for professional antigen presentation; the presence of co-stimulatory molecules is necessary for cells to act as professional APCs, as defined by the ability to present antigen to naive $\mathrm{T}$ cells, resulting in their activation (Schwartz, 2001). Ohkawara et al. (1996) demonstrated that eosinophils isolated from the peripheral blood of mildly atopic subjects express the co-stimulatory protein CD40. Two major co-stimulatory molecules, CD80 and CD86, have been shown in murine experimental models of allergic lower airway inflammation to be expressed on eosinophils recovered from these sites (Shi et al., 2000; MacKenzie et al., 2001). In addition, antigen loaded murine eosinophils elicited proliferation of $\mathrm{T}$ cells in vitro that was inhibited by the presence of anti-CD80 and anti-CD86 Abs (Tamura et al., 1996; Shi et al., 2000).

\section{ETosis}

Under conditions of chronic inflammation in allergic asthma, neutrophils along with eosinophils are the first cells to be recruited to inflammatory sites (Baggiolini, 1998; Agrawal and Shao, 2010). Neutrophils, which are the most abundant leukocytes in the blood, use two basic strategies to eliminate microorganisms (GuimaraesCosta et al., 2012). They can kill microorganisms via phagocytosis, which involves ingestion and killing of microorganisms inside special compartments of the cell. Alternatively, they can kill microorganisms via degranulation, which consists of extravasation of the granular contents to the extracellular milieu. In addition to these two mechanisms, recent studies have identified a new antimicrobial mechanism that neutrophils can use to eliminate microbes. This mechanism was first termed NETosis in reference to the neutrophil extracellular traps that are deployed into the extracellular milieu when DNA-associated proteins are expelled from the cell to eliminate microbes (Brinkmann et al., 2004; Brinkmann and Zychlinsky, 2007; Guimaraes-Costa et al., 2012). NETosis has been observed in many experimental models of fungal and bacterial infections (Urban et al., 2006; Bruns et al., 2010; Guimaraes-Costa et al., 2012). However, it is now recognized that other cell types such as eosinophils and mast cells may also use extracellular traps (von Kockritz-Blickwede et al., 2008; Yousefi et al., 2008). Monocytes and macrophages have also been shown to release ETs but to a lesser extent than that of granulocytes (Webster et al., 2010). Since this general mechanism is now known to be shared by different cell types, the release of ETs was termed as ETosis, meaning death with release of DNA extracellular traps (Guimaraes-Costa et al., 2012).

ETosis seems to be a well-conserved mechanism in eosinophils, as studies have shown extracellular DNA with ECP and MBP in the innate defense mechanism against helminths and bacteria in gastrointestinal infections (Yousefi et al., 2008). The extracellular DNA activity (i.e., ETosis) of intact eosinophils might be particularly crucial against fungi and other pathogens at the surface of the mucosa and may well play an important role in fungal allergic asthma where eosinophils are present in large numbers in the airway lumen and the lung (Clark et al., 2004; Hoselton et al., 2010). Further studies on the role of ETosis in impacting eosinophil function at the mucosal interface would have important implications in understanding the role of ETosis in eosinophil activation in health and disease.

\section{CONCLUSION}

Observations from experimental animals and asthmatic patients suggest a direct participation of eosinophils in mediating the pathophysiology associated with allergic/fungal asthma, although the mechanisms by which eosinophils contribute to the pathogenesis are rather complicated. Eosinophils have been considered end-stage cells in immunopathology of fungal allergic asthma. However, emerging evidence suggests that eosinophils have a broad range of functions beyond that of a basic granulocyte in allergic asthma and that they promote more than one aspect of respiratory dysfunction which are associated with allergic/fungal 
asthma. The initiation and maintenance of allergic/fungal asthma relies on the balance between the early and late phase inflammatory response. Hence, the possibility of drugs directed at inhibiting eosinophil migration, activation, or even outright eosinophil ablation might prove to be effective therapeutic strategies. Furthermore, a directed exploration of the factors permitting prolonged survival of eosinophils in tissue, even in the presence of effective IL-5 blockade, might uncover additional eosinophil depletion strategies. Thus, further studies using in vivo eosinophil deficient mice and further characterization of the immunobiology of eosinophils in vitro will be necessary to answer critical questions concerning the involvement of these leukocytes in

\section{REFERENCES}

Abu-Ghazaleh, R. I., Fujisawa, T., Mestecky, J., Kyle, R. A., and Gleich, G. J. (1989). IgA-induced eosinophil degranulation. J. Immunol. 142, 2393-2400.

Adachi, T., and Alam, R. (1998). The mechanism of IL-5 signal transduction. Am. J. Physiol. 275, C623-C633.

Agrawal, D. K., and Shao, Z. (2010). Pathogenesis of allergic airway inflammation. Curr. Allergy Asthma Rep. 10, 39-48.

Alam, R., York, J., Boyars, M., Stafford, S., Grant, J. A., Lee, J., et al. (1996). Increased MCP-1, RANTES, and MIP-lalpha in bronchoalveolar lavage fluid of allergic asthmatic patients. Am. J. Respir. Crit. Care Med. 153, 1398-1404.

Ames, R. S., Li, Y., Sarau, H. M., Nuthulaganti, P., Foley, J. J., Ellis, C., et al. (1996). Molecular cloning and characterization of the human anaphylatoxin C3a receptor. J. Biol. Chem. 271, 20231-20234.

Amin, K. (2012). The role of mast cells in allergic inflammation. Respir. Med. 106, 9-14.

Anwar, A. R., Moqbel, R., Walsh, G. M., Kay, A. B., and Wardlaw, A. J. (1993). Adhesion to fibronectin prolongs eosinophil survival. J. Exp. Med. 177, 839-843.

Arm, J. P., and Lee, T. H. (1992). The pathobiology of bronchial asthma. Adv. Immunol. 51, 323-382.

Aukrust, L. (1979). Crossed radioimmunoelectrophoretic studies of distinct allergens in two extracts of Cladosporium herbarum. Int. Arch. Allergy Appl. Immunol. 58, 375-390.

Ayars, G. H., Altman, L. C., McManus, M. M., Agosti, J. M., Baker, C., Luchtel, D. L., et al. (1989). Injurious effect of the eosinophil peroxidehydrogen peroxide-halide system and major basic protein on human nasal epithelium in vitro. Am. Rev. Respir. Dis. 140, 125-131.

Baelder, R., Fuchs, B., Bautsch, W., Zwirner, J., Kohl, J., Hoymann, H. G., et al. (2005). Pharmacological targeting of anaphylatoxin receptors during the effector phase of allergic asthma suppresses airway hyperresponsiveness and airway inflammation. J. Immunol. 174, 783-789.

Baggiolini, M. (1998). Chemokines and leukocyte traffic. Nature 392, 565-568.

Bagley, C. J., Woodcock, J. M., Stomski, F. C., and Lopez, A. F. (1997). The structural and functional basis of cytokine receptor activation: lessons from the common beta subunit of the granulocytemacrophage colony-stimulating factor, interleukin-3 (IL-3), and IL-5 receptors. Blood 89, 1471-1482.

Bandeira-Melo, C., and Weller, P. F. (2003). Eosinophils and cysteinyl leukotrienes. Prostaglandins Leukot. Essent. Fatty Acids 69, 135-143.

Barnes, P. J. (2008). The cytokine network in asthma and chronic obstructive pulmonary disease. J. Clin. Invest. 118, 3546-3556.

Bartemes, K. R., Cooper, K. M., Drain, K. L., and Kita, H. (2005). Secretory IgA induces antigenindependent eosinophil survival and cytokine production without inducing effector functions. J. Allergy Clin. Immunol. 116, 827-835.

Barthel, S. R., Johansson, M. W., McNamee, D. M., and Mosher, D. F. (2008). Roles of integrin activation in eosinophil function and the eosinophilic inflammation of asthma. J. Leukoc. Biol. 83, 1-12.

Beck, O., Topp, M. S., Koehl, U., Roilides, E., Simitsopoulou, M., Hanisch, M., et al. (2006). Generation of highly purified and functionally active human TH1 cells against Aspergillus fumigatus. Blood 107, 2562-2569.

Bellido-Casado, J., Plaza, V., Perpina, M., Picado, C., Bardagi, S., MartinezBru, C., et al. (2010). Inflammatory response of rapid onset asthma exacerbation. Arch. Bronconeumol. 46, 587-593.

Bloemen, K., Verstraelen, S., Van Den Heuvel, R., Witters, H., Nelissen, I., and Schoeters, G. (2007). The allergic cascade: review of the most

fungal asthma. Among the avenues that that might be considered is the possibility by which eosinophils integrate and prioritize the extra-and intracellular signals from the collective actions of cytokines, chemokines, and the role of VIP/VPAC2/CRTH2 signaling and ECM components like hyaluronic acid in eosinophil chemotaxis/migration will allow the development of specific therapeutic targets which can further attenuate specific components of the fungal allergic response. Furthermore, studies involving the recognition of epigenetic factors in regulating the inflammatory genes in fungus-associated pulmonary allergic disease may lead to new therapeutic approaches in the future.

important molecules in the asthmatic lung. Immunol. Lett. 113 6-18.

Boldajipour, B., Mahabaleshwar, H. Kardash, E., Reichman-Fried, M. Blaser, H., Minina, S., et al. (2008). Control of chemokine-guided cell migration by ligand sequestration. Cell 132, 463-473.

Borchers, M. T., Ansay, T., Desalle, R. Daugherty, B. L., Shen, H., Metzger, M., et al. (2002). In vitro assessment of chemokine receptorligand interactions mediating mouse eosinophil migration. J. Leukoc. Biol. 71, 1033-1041.

Bosiger, J., and Fehr, J. (2006). [Mast cells and basophils and their disorders]. Ther. Umsch. 63, 89-97.

Boutet, K., Malo, J. L., Ghezzo, H., and Gautrin, D. (2007). Airway hyperresponsiveness and risk of chest symptoms in an occupational model. Tho$\operatorname{rax} 62,260-264$.

Boxall, C., Holgate, S. T., and Davies, D. E. (2006). The contribution of transforming growth factor-beta and epidermal growth factor signalling to airway remodelling in chronic asthma. Eur. Respir. J. 27, 208-229.

Brinkmann, V., Reichard, U., Goosmann, C., Fauler, B., Uhlemann, Y., Weiss, D. S., et al. (2004). Neutrophil extracellular traps kill bacteria. Science 303, 1532-1535.

Brinkmann, V., and Zychlinsky, A. (2007). Beneficial suicide: why neutrophils die to make NETs. Nat. Rev. Microbiol. 5, 577-582.

Broide, D. H., Humber, D., Sullivan, S., and Sriramarao, P. (1998). Inhibition of eosinophil rolling and recruitment in P-selectin- and intracellular adhesion molecule-1deficient mice. Blood 91, 2847-2856.

Bruns, S., Kniemeyer, O., Hasenberg, M., Aimanianda, V., Nietzsche, S., Thywissen, A., et al. (2010). Production of extracellular traps against Aspergillus fumigatus in vitro and in infected lung tissue is dependent on invading neutrophils and influenced by hydrophobin
RodA. PLoS Pathog. 6:e1000873. doi:10.1371/journal.ppat.1000873

Bundy, K. W., Gent, J. F., Beckett, W., Bracken, M. B., Belanger, K., Triche, E., et al. (2009). Household airborne Penicillium associated with peak expiratory flow variability in asthmatic children. Ann. Allergy Asthma Immunol. 103, 26-30.

Butterworth, A. E., Sturrock, R. F., Houba, V., Mahmoud, A. A., Sher, A., and Rees, P. H. (1975). Eosinophils as mediators of antibody-dependent damage to schistosomula. Nature 256, 727-729.

Campos, L. E., and Pereira, L. F. (2009). Pulmonary eosinophilia. J. Bras. Pneumol. 35, 561-573.

Capron, M., Tomassini, M., Torpier, G., Kusnierz, J. P., MacDonald, S., and Capron, A. (1989). Selectivity of mediators released by eosinophils. Int. Arch. Allergy Appl. Immunol. 88, 54-58.

Chatterjee, R., Batra, J., Das, S., Sharma, S. K., and Ghosh, B. (2008). Genetic association of acidic mammalian chitinase with atopic asthma and serum total IgE levels. J. Allergy Clin. Immunol. 122, 202-208, 208, e201-e207.

Cho, J. Y., Miller, M., Baek, K. J., Han, J. W., Nayar, J., Lee, S. Y., et al. (2004). Inhibition of airway remodeling in IL-5-deficient mice. J. Clin. Invest. 113, 551-560.

Choi, E. N., Choi, M. K., Park, C. S. and Chung, I. Y. (2003). A parallel signal-transduction pathway for eotaxin- and interleukin-5-induced eosinophil shape change. Immunology 108, 245-256.

Christodoulopoulos, P., Cameron, L., Durham, S., and Hamid, Q. (2000). Molecular pathology of allergic disease. II: upper airway disease. J. Allergy Clin. Immunol. 105, 211-223.

Claman, D. M., Boushey, H. A., Liu, J., Wong, H., and Fahy, J. V. (1994). Analysis of induced sputum to examine the effects of prednisone on airway inflammation in asthmatic subjects. J. Allergy Clin. Immunol. 94, 861-869. 
Clark, K., Simson, L., Newcombe, N., Koskinen, A. M., Mattes, J., Lee, N. A., et al. (2004). Eosinophil degranulation in the allergic lung of mice primarily occurs in the airway lumen. $J$. Leukoc. Biol. 75, 1001-1009.

Collins, P. D., Marleau, S., GriffithsJohnson, D. A., Jose, P. J., and Williams, T. J. (1995). Cooperation between interleukin-5 and the chemokine eotaxin to induce eosinophil accumulation in vivo. $J$. Exp. Med. 182, 1169-1174.

Conroy, D. M., and Williams, T. J. (2001). Eotaxin and the attraction of eosinophils to the asthmatic lung. Respir. Res. 2, 150-156.

Conti, P., and Digioacchino, M. (2001). MCP-1 and RANTES are mediators of acute and chronic inflammation. Allergy Asthma Proc. 22, 133-137.

Cook, E. B., Stahl, J. L., Lilly, C. M., Haley, K. J., Sanchez, H., Luster, A. D., et al. (1998). Epithelial cells are a major cellular source of the chemokine eotaxin in the guinea pig lung. Allergy Asthma Proc. 19, 15-22.

Daffern, P. J., Pfeifer, P. H., Ember, J. A., and Hugli, T. E. (1995). C3a is a chemotaxin for human eosinophils but not for neutrophils. I. C3a stimulation of neutrophils is secondary to eosinophil activation. J. Exp. Med. 181, 2119-2127.

Dagenais, T. R., and Keller, N. P. (2009). Pathogenesis of Aspergillus fumigatus in Invasive Aspergillosis. Clin. Microbiol. Rev. 22, 447-465.

Dahinden, C. A., Geiser, T., Brunner, T., Von Tscharner, V., Caput, D., Ferrara, P., et al. (1994). Monocyte chemotactic protein 3 is a most effective basophil- and eosinophilactivating chemokine. J. Exp. Med. $179,751-756$.

Denning, D. W., O’Driscoll, B. R., Hogaboam, C. M., Bowyer, P., and Niven, R. M. (2006). The link between fungi and severe asthma: a summary of the evidence. Eur. Respir. J. 27, 615-626.

Discipio, R. G., Daffern, P. J., Jagels, M. A., Broide, D. H., and Sriramarao, P. (1999). A comparison of C3a and C5a-mediated stable adhesion of rolling eosinophils in postcapillary venules and transendothelial migration in vitro and in vivo. $J$. Immunol. 162, 1127-1136.

Discipio, R. G., and Schraufstatter, I. U. (2007). The role of the complement anaphylatoxins in the recruitment of eosinophils. Int. Immunopharmacol. 7, 1909-1923.

Doherty, T., and Broide, D. (2007). Cytokines and growth factors in airway remodeling in asthma. Curr. Opin. Immunol. 19, 676-680.
Dorman, S. C., Babirad, I., Post, J., Watson, R. M., Foley, R., Jones, G. L., et al. (2005). Progenitor egress from the bone marrow after allergen challenge: role of stromal cell-derived factor lalpha and eotaxin. J. Allergy Clin. Immunol. 115, 501-507.

Douwes, J., Zuidhof, A., Doekes, G., Van Der Zee, S. C., Wouters, I., Boezen, M. H., et al. (2000). (1 $\rightarrow 3)$-beta-Dglucan and endotoxin in house dust and peak flow variability in children. Am. J. Respir. Crit. Care Med. 162, 1348-1354.

Dunzendorfer, S., Meierhofer, C., and Wiedermann, C. J. (1998). Signaling in neuropeptide-induced migration of human eosinophils. J. Leukoc. Biol. 64, 828-834.

Elovic, A. E., Ohyama, H., Sauty, A., McBride, J., Tsuji, T., Nagai, M., et al. (1998). IL-4-dependent regulation of TGF-alpha and TGF-betal expression in human eosinophils. $J$. Immunol. 160, 6121-6127.

El-Shazly, A., Masuyama, K., Tsunoda, N., Eura, M., and Ishikawa, T. (2000). Non-specific activation of human eosinophil functional responses by vasoactive intestinal peptide. Allergol. Int. 49, 19-26.

El-Shazly, A. E., Begon, D. Y., Kustermans, G., Arafa, M., Dortu, E., Henket, M., et al. (2013). Novel association between vasoactive intestinal peptide and CRTH2 receptor in recruiting eosinophils: a possible biochemical mechanism for allergic eosinophilic inflammation of the airways. J. Biol. Chem. 288, 1374-1384.

El-Shazly, A. E., Henket, M., Lefebvre, P. P., and Louis, R. (2011). 2B4 (CD244) is involved in eosinophil adhesion and chemotaxis, and its surface expression is increased in allergic rhinitis after challenge. Int. J. Immunopathol. Pharmacol. 24, 949-960.

El-Shazly, A. E., Masuyama, K., Samejima, Y., Eura, M., and Ishikawa, T. (1996). Inhibition of human eosinophil chemotaxis in vitro by the anti-allergic agent emedastine difumarate. Immunopharmacol. Immunotoxicol. 18, 587-595.

Elsner, J., and Kapp, A. (1999). Regulation and modulation of eosinophil effector functions. Allergy 54, 15-26.

Erjefalt, J. S., and Persson, C. G. (2000). New aspects of degranulation and fates of airway mucosal eosinophils. Am. J. Respir. Crit. Care Med. 161, 2074-2085.

Fahy, J. V. (2009). Eosinophilic and neutrophilic inflammation in asthma: insights from clinical studies. Proc. Am. Thorac. Soc. 6, 256-259.
Fine, A., and Goldstein, R. H. (1993). Regulation of type I collagen mRNA translation by TGF-beta. Reg. Immunol. 5, 218-224.

Fisk, W. J., Lei-Gomez, Q., and Mendell, M. J. (2007). Meta-analyses of the associations of respiratory health effects with dampness and mold in homes. Indoor Air 17, 284-296.

Flood-Page, P., Menzies-Gow, A. Phipps, S., Ying, S., Wangoo, A., Ludwig, M. S., et al. (2003). AntiIL-5 treatment reduces deposition of ECM proteins in the bronchial subepithelial basement membrane of mild atopic asthmatics. J. Clin. Invest. 112, 1029-1036.

Foster, P. S., Mould, A. W., Yang, M., MacKenzie, J., Mattes, J., Hogan, S. P., et al. (2001). Elemental signals regulating eosinophil accumulation in the lung. Immunol. Rev. 179, 173-181.

Frigas, E., Loegering, D. A., Solley, G. O., Farrow, G. M., and Gleich, G. J. (1981). Elevated levels of the eosinophil granule major basic protein in the sputum of patients with bronchial asthma. Mayo Clin. Proc. 56, 345-353.

Fryer, A. D., and Jacoby, D. B. (1998). Muscarinic receptors and control of airway smooth muscle. Am. J. Respir. Crit. Care Med. 158, S154-S160.

Galli, S. J. (2000). Mast cells and basophils. Curr. Opin. Hematol. 7, 32-39.

Garcia-Zepeda, E. A., Rothenberg, M. E., Ownbey, R. T., Celestin, J., Leder, P., and Luster, A. D. (1996). Human eotaxin is a specific chemoattractant for eosinophil cells and provides a new mechanism to explain tissue eosinophilia. Nat. Med. 2, 449-456.

Gascoigne, M. H., Holland, K., Page, C. P., Shock, A., Robinson, M., Foulkes, R., et al. (2003). The effect of antiintegrin monoclonal antibodies on antigen-induced pulmonary inflammation in allergic rabbits. Pulm. Pharmacol. Ther. 16, 279-285.

Gavett, S. H., Chen, X., Finkelman, F., and Wills-Karp, M. (1994). Depletion of murine CD4+ T lymphocytes prevents antigen-induced airway hyperreactivity and pulmonary eosinophilia. Am. J. Respir. Cell Mol. Biol. 10, 587-593.

Georas, S. N., McIntyre, B. W., Ebisawa, M., Bednarczyk, J. L., Sterbinsky, S. A., Schleimer, R. P., et al. (1993). Expression of a functional laminin receptor (alpha 6 beta 1 , very late activation antigen-6) on human eosinophils. Blood 82, 2872-2879.

Ghosh, S., Hoselton, S. A., and Schuh, J. M. (2012). mu-Chain-deficient mice possess B-1 cells and produce IgG and IgE, but NOT IgA, following systemic sensitization and inhalational challenge in a fungal asthma model. J. Immunol. 189, 1322-1329.

Girodet, P. O., Ozier, A., Bara, I., Tunon De Lara, J. M., Marthan, R., and Berger, P. (2011). Airway remodeling in asthma: new mechanisms and potential for pharmacological intervention. Pharmacol. Ther. 130, 325-337.

Gleich, G. J. (2000). Mechanisms of eosinophil-associated inflammation. J. Allergy Clin. Immunol. 105, 651-663.

Gonzalo, J. A., Lloyd, C. M., Kremer, L., Finger, E., Martinez, A. C., Siegelman, M. H., et al. (1996). Eosinophil recruitment to the lung in a murine model of allergic inflammation. The role of $\mathrm{T}$ cells, chemokines, and adhesion receptors. J. Clin. Invest. 98 , 2332-2345.

Gonzalo, J. A., Lloyd, C. M., Wen, D., Albar, J. P., Wells, T. N., Proudfoot, A., et al. (1998). The coordinated action of CC chemokines in the lung orchestrates allergic inflammation and airway hyperresponsiveness. $J$. Exp. Med. 188, 157-167.

Goodridge, H. S., Wolf, A. J., and Underhill, D. M. (2009). Betaglucan recognition by the innate immune system. Immunol. Rev. 230, 38-50.

Gounni, A. S., Lamkhioued, B., Ochiai, K., Tanaka, Y., Delaporte, E., Capron, A., et al. (1994). High-affinity IgE receptor on eosinophils is involved in defence against parasites. Nature 367, 183-186.

Grayson, M. H., Van Der Vieren, M., Sterbinsky, S. A., Michael Gallatin, W., Hoffman, P. A., Staunton, D. E., et al. (1998). Alphadbeta2 integrin is expressed on human eosinophils and functions as an alternative ligand for vascular cell adhesion molecule 1 (VCAM-1). J. Exp. Med. 188, 2187-2191.

Grazziutti, M. L., Rex, J. H., Cowart, R. E., Anaissie, E. J., Ford, A., and Savary, C. A. (1997). Aspergillus fumigatus conidia induce a Th1type cytokine response. J. Infect. Dis. 176, 1579-1583.

Gregory, B., Kirchem, A., Phipps, S., Gevaert, P., Pridgeon, C., Rankin, S. M., et al. (2003). Differential regulation of human eosinophil IL-3, IL-5, and GM-CSF receptor alpha-chain expression by cytokines: IL-3, IL-5, and GM-CSF downregulate IL-5 receptor alpha expression with loss of IL-5 responsiveness, but up-regulate IL-3 receptor alpha expression. J. Immunol. 170, 5359-5366. 
Grunig, G., Warnock, M., Wakil, A. E., Venkayya, R., Brombacher, F., Rennick, D. M., et al. (1998). Requirement for IL-13 independently of IL4 in experimental asthma. Science 282, 2261-2263.

Guimaraes-Costa, A. B., Nascimento, M. T., Wardini, A. B., Pinto-Da-Silva, L. H., and Saraiva, E. M. (2012). ETosis: a microbicidal mechanism beyond cell death. J. Parasitol. Res. 2012, 929743.

Guo, R. F., and Ward, P. A. (2005). Role of $\mathrm{C} 5 \mathrm{a}$ in inflammatory responses. Annu. Rev. Immunol. 23, 821-852.

Gutierrez-Ramos, J. C., Lloyd, C., and Gonzalo, J. A. (1999). Eotaxin: from an eosinophilic chemokine to a major regulator of allergic reactions. Immunol. Today 20, 500-504.

Hafez, I., Stolpe, A., and Lindau, M. (2003). Compound exocytosis and cumulative fusion in eosinophils. $J$. Biol. Chem. 278, 44921-44928.

Hagmann, W. K. (2004). The discovery and potential of $\mathrm{N}$-sulfonylated dipeptide VLA-4 antagonists. Curr. Top. Med. Chem. 4, 1461-1471.

Haldar, P., Brightling, C. E., Hargadon, B., Gupta, S., Monteiro, W., Sousa, A., et al. (2009). Mepolizumab and exacerbations of refractory eosinophilic asthma. N. Engl. J. Med. 360, 973-984.

Hall, A. (1998). G proteins and small GTPases: distant relatives keep in touch. Science 280, 2074-2075.

Hamid, Q., and Tulic, M. (2009). Immunobiology of asthma. Annu. Rev. Physiol. 71, 489-507.

Hansel, T. T., Braun, R. K., De Vries, I. J., Boer, C., Boer, L., Rihs, S., et al. (1993). Eosinophils and cytokines. Agents Actions Suppl. 43, 197-208.

Hansel, T. T., Braunstein, J. B., Walker, C., Blaser, K., Bruijnzeel, P. L., Virchow, J. C. Jr., et al. (1991). Sputum eosinophils from asthmatics express ICAM-1 and HLA-DR. Clin. Exp. Immunol. 86, 271-277.

Hara, K., Hasegawa, T., Ooi, H., Koya, T., Tanabe, Y., Tsukada, H., et al. (2001). Inhibitory role of eosinophils on cell surface plasmin generation by bronchial epithelial cells: inhibitory effects of transforming growth factor beta. Lung 179, 9-20.

Henning, S. W., and Cantrell, D. A. (1998). GTPases in antigen receptor signalling. Curr. Opin. Immunol. 10, 322-329.

Hirasawa, R., Shimizu, R., Takahashi, S., Osawa, M., Takayanagi, S., Kato, Y., et al. (2002). Essential and instructive roles of GATA factors in eosinophil development. J. Exp. Med. 195, 1379-1386.
Hogaboam, C. M., Blease, K., Mehrad, B., Steinhauser, M. L., Standiford, T. J., Kunkel, S. L., et al. (2000). Chronic airway hyperreactivity, goblet cell hyperplasia, and peribronchial fibrosis during allergic airway disease induced by Aspergillus fumigatus. Am. J. Pathol. 156, 723-732.

Hogaboam, C. M., Blease, K., and Schuh, J. M. (2003). Cytokines and chemokines in allergic bronchopulmonary aspergillosis (ABPA) and experimental Aspergillus-induced allergic airway or asthmatic disease. Front. Biosci. 8, e147-e156.

Hogaboam, C. M., Carpenter, K. J., Schuh, J. M., and Buckland, K. F. (2005). Aspergillus and asthma any link? Med. Mycol. 43(Suppl. 1), S197-S202.

Hogg, N., Patzak, I., and Willenbrock, F. (2011). The insider's guide to leukocyte integrin signalling and function. Nat. Rev. Immunol. 11, 416-426.

Hohl, T. M. (2008). Stage-specific innate immune recognition of Aspergillus fumigatus and modulation by echinocandin drugs. Med. Mycol. PMID:18608931. [Epub ahead of print].

Holgate, S. T., Bodey, K. S., Janezic, A., Frew, A. J., Kaplan, A. P., and Teran, L. M. (1997). Release of RANTES, MIP-1 alpha, and MCP1 into asthmatic airways following endobronchial allergen challenge. Am. J. Respir. Crit. Care Med. 156, 1377-1383.

Horner, W. E., Helbling, A., Salvaggio, J. E., and Lehrer, S. B. (1995). Fungal allergens. Clin. Microbiol. Rev. 8, 161-179.

Horwitz, R. J., and Busse, W. W. (1995). Inflammation and asthma. Clin. Chest Med. 16, 583-602.

Hoselton, S. A., Samarasinghe, A. E., Seydel, J. M., and Schuh, J. M. (2010). An inhalation model of airway allergic response to inhalation of environmental Aspergillus fumigatus conidia in sensitized BALB/c mice. Med. Mycol. 48, 1056-1065.

Hoshino, M., Sim, J., Shimizu, K., Nakayama, H., and Koya, A. (1999). Effect of AA-2414, a thromboxane $\mathrm{A} 2$ receptor antagonist, on airway inflammation in subjects with asthma. J. Allergy Clin. Immunol. 103, 1054-1061.

Hugli, T. E. (1986). Biochemistry and biology of anaphylatoxins. Complement 3, 111-127.

Humbles, A. A., Lloyd, C. M., McMillan, S. J., Friend, D. S., Xanthou, G., McKenna, E. E., et al. (2004). A critical role for eosinophils in allergic airways remodeling. Science 305, 1776-1779.

Humbles, A. A., Lu, B., Nilsson, C. A., Lilly, C., Israel, E., Fujiwara, Y., et al. (2000). A role for the C3a anaphylatoxin receptor in the effector phase of asthma. Nature 406, 998-1001.

Humphries, M. J. (2004). Monoclonal antibodies as probes of integrin priming and activation. Biochem. Soc. Trans. 32, 407-411.

Hwang, S. B. (1990). Specific receptors of platelet-activating factor, receptor heterogeneity, and signal transduction mechanisms. J. Lipid Mediat. 2, 123-158.

Jacoby, D. B., Gleich, G. J., and Fryer, A. D. (1993). Human eosinophil major basic protein is an endogenous allosteric antagonist at the inhibitory muscarinic M2 receptor. J. Clin. Invest. 91, 1314-1318.

Jagels, M. A., Daffern, P. J., and Hugli, T. E. (2000). C3a and C5a enhance granulocyte adhesion to endothelial and epithelial cell monolayers: epithelial and endothelial priming is required for $\mathrm{C} 3 \mathrm{a}$-induced eosinophil adhesion. Immunopharmacology 46 , 209-222.

Jeffery, P. K. (2001). Remodeling in asthma and chronic obstructive lung disease. Am. J. Respir. Crit. Care Med. 164, S28-S38

Jia, G. Q., Gonzalo, J. A., Hidalgo, A., Wagner, D., Cybulsky, M., and Gutierrez-Ramos, J. C. (1999) Selective eosinophil transendothelial migration triggered by eotaxin via modulation of Mac-1/ICAM1 and VLA-4/VCAM-1 interactions. Int. Immunol. 11, 1-10.

Johansson, A. K., Sjostrand, M., Tomaki, M., Samulesson, A. M., and Lotvall, J. (2004). Allergen stimulates bone marrow CD34(+) cells to release IL5 in vitro; a mechanism involved in eosinophilic inflammation? Allergy 59, 1080-1086.

Justice, J. P., Borchers, M. T., Crosby, J. R., Hines, E. M., Shen, H. H., Ochkur, S. I., et al. (2003). Ablation of eosinophils leads to a reduction of allergen-induced pulmonary pathology. Am. J. Physiol. Lung Cell Mol. Physiol. 284, L169-L178.

Kariyawasam, H. H., and Robinson, D. S. (2005). Airway remodelling in asthma: models and supermodels? Clin. Exp. Allergy 35, 117-121.

Kariyawasam, H. H., and Robinson, D. S. (2007). The role of eosinophils in airway tissue remodelling in asthma. Curr. Opin. Immunol. 19, 681-686.

Karvonen, A. M., Hyvarinen, A., Roponen, M., Hoffmann, M., Korppi, M., Remes, S., et al. (2009). Confirmed moisture damage at home, respiratory symptoms and atopy in early life: a birth-cohort study. Pediatrics 124, e329-e338.

Kato, M., Kita, H., Tachibana, A. Hayashi, Y., Tsuchida, Y., and Kimura, H. (2004). Dual signaling and effector pathways mediate human eosinophil activation by platelet-activating factor. Int. Arch. Allergy Immunol. 134(Suppl. 1), 37-43.

Kay, A. B. (1983). Mediators of hypersensitivity and inflammatory cells in the pathogenesis of bronchial asthma. Eur. J. Respir. Dis. Suppl. 129, $1-44$.

Kay, A. B. (1988). Leucocytes in asthma. Immunol. Invest. 17, 679-705.

Kay, A. B., and Klion, A. D. (2004). Antiinterleukin-5 therapy for asthma and hypereosinophilic syndrome. Immunol. Allergy Clin. North Am. 24, 645-666, vii.

Kay, A. B., Phipps, S., and Robinson, D. S. (2004). A role for eosinophils in airway remodelling in asthma. Trends Immunol. 25, 477-482.

Kayaba, H., and Chihara, J. (2001). Eosinophils and related chemokines. Rinsho Byori 49, 370-375.

Kenyon, N. J., Ward, R. W., McGrew, G., and Last, J. A. (2003). TGF-beta1 causes airway fibrosis and increased collagen I and III mRNA in mice. Thorax 58, 772-777.

Khalid, A. N., Woodworth, B. A., Prince, A., Quraishi, S. A., Antunes, M. B., Long, F. H., et al. (2008). Physiologic alterations in the murine model after nasal fungal antigenic exposure. Otolaryngol. Head Neck Surg. 139, 695-701.

Khan, L. N., Kon, O. M., MacFarlane, A. J., Meng, Q., Ying, S., Barnes, N. C., et al. (2000). Attenuation of the allergen-induced late asthmatic reaction by cyclosporin A is associated with inhibition of bronchial eosinophils, interleukin-5, granulocyte macrophage colony-stimulating factor, and eotaxin. Am. J. Respir. Crit. Care Med. 162, 1377-1382.

Kita, H. (2011). Eosinophils: multifaceted biological properties and roles in health and disease. Immunol. Rev. 242, 161-177.

Kita, H., Kaneko, M., Bartemes, K. R., Weiler, D. A., Schimming, A. W., Reed, C. E., et al. (1999). Does IgE bind to and activate eosinophils from patients with allergy? $J$. Immunol. 162, 6901-6911.

Kita, H., Weiler, D. A., Abu-Ghazaleh, R., Sanderson, C. J., and Gleich, G. J. (1992). Release of granule proteins from eosinophils cultured with IL-5. J. Immunol. 149, 629-635. 
Knutsen, A. P., Bush, R. K., Demain, J. G., Denning, D. W., Dixit, A., Fairs, A., et al. (2012). Fungi and allergic lower respiratory tract diseases. J. Allergy Clin. Immunol. 129, 280-291; quiz 292-283.

Knutsen, A. P., and Slavin, R. G. (2011). Allergic bronchopulmonary aspergillosis in asthma and cystic fibrosis. Clin. Dev. Immunol. 2011, 843763.

Koeffler, H. P., Billing, R., Levine, A. M., and Golde, D. W. (1980). Ia antigen is a differentiation marker on human eosinophils. Blood 56, 11-14.

Koo, G. C., Shah, K., Ding, G. J., Xiao, J., Wnek, R., Doherty, G., et al. (2003). A small molecule very late antigen-4 antagonist can inhibit ovalbumin-induced lung inflammation. Am. J. Respir. Crit. Care Med. 167, 1400-1409.

Kotsimbos, A. T., and Hamid, Q. (1997). IL-5 and IL-5 receptor in asthma. Mem. Inst. Oswaldo Cruz 92(Suppl. 2), 75-91.

Kupczyk, M., and Kuna, P. (1999). [The role of leukotrienes in inflammation and leukotriene inhibitors]. Pol. Merkur. Lekarski 7, 85-93.

Kvarnhammar, A. M., and Cardell, L. O. (2012). Pattern-recognition receptors in human eosinophils. Immunology 136, 11-20.

Lacoste, J. Y., Bousquet, J., Chanez, P., Van Vyve, T., Simony-Lafontaine, J., Lequeu, N., et al. (1993). Eosinophilic and neutrophilic inflammation in asthma, chronic bronchitis, and chronic obstructive pulmonary disease. J. Allergy Clin. Immunol. 92, 537-548.

Lacy, P., Mahmudi-Azer, S., Bablitz, B., Hagen, S. C., Velazquez, J. R., Man, S. F., et al. (1999). Rapid mobilization of intracellularly stored RANTES in response to interferon-gamma in human eosinophils. Blood 94, 23-32.

Lamkhioued, B., Renzi, P. M., AbiYounes, S., Garcia-Zepada, E. A., Allakhverdi, Z., Ghaffar, O., et al. (1997). Increased expression of eotaxin in bronchoalveolar lavage and airways of asthmatics contributes to the chemotaxis of eosinophils to the site of inflammation. J. Immunol. 159, 4593-4601.

Latge, J. P. (1999). Aspergillus fumigatus and aspergillosis. Clin. Microbiol. Rev. 12, 310-350.

Le, Y., Zhou, Y., Iribarren, P., and Wang, J. (2004). Chemokines and chemokine receptors: their manifold roles in homeostasis and disease. Cell. Mol. Immunol. 1, 95-104.

Leavy, O. (2008). Allergy and asthma: regulation of TGF[beta] 1 PINned down. Nat. Rev. Immunol. 8, 164-165.

Lee, J. J., McGarry, M. P., Farmer, S. C., Denzler, K. L., Larson, K. A., Carrigan, P. E., et al. (1997). Interleukin-5 expression in the lung epithelium of transgenic mice leads to pulmonary changes pathognomonic of asthma. J. Exp. Med. 185, 2143-2156.

Li, L., Xia, Y., Nguyen, A., Lai, Y. H., Feng, L., Mosmann, T. R., et al. (1999). Effects of Th2 cytokines on chemokine expression in the lung: IL-13 potently induces eotaxin expression by airway epithelial cells. J. Immunol. 162, 2477-2487.

Lin, S. J., Schranz, J., and Teutsch, S. M. (2001). Aspergillosis case-fatality rate: systematic review of the literature. Clin. Infect. Dis. 32, 358-366.

Lindell, D. M., Berlin, A. A., Schaller, M. A., and Lukacs, N. W. (2008). B cell antigen presentation promotes Th2 responses and immunopathology during chronic allergic lung disease. PLoS ONE 3:e3129. doi:10.1371/journal.pone.0003129

Liu, C. T., Wang, K., Li, L., and Pang, Y. M. (2006). [The roles of interleukin5 and eotaxin in signal transmission between lung and bone marrow of rat asthmatic models]. Zhonghua Jie He He Hu Xi Za Zhi 29, 558-562.

Lloyd, C. M., Delaney, T., Nguyen, T., Tian, J., Martinez, A. C., Coyle, A. J., et al. (2000). CC chemokine receptor (CCR)3/eotaxin is followed by CCR4/monocyte-derived chemokine in mediating pulmonary T helper lymphocyte type 2 recruitment after serial antigen challenge in vivo. J. Exp. Med. 191, 265-274.

Lloyd, C. M., and Rankin, S. M. (2003). Chemokines in allergic airway disease. Curr. Opin. Pharmacol. 3, 443-448.

Logan, M. R., Odemuyiwa, S. O., and Moqbel, R. (2003). Understanding exocytosis in immune and inflammatory cells: the molecular basis of mediator secretion. J. Allergy Clin. Immunol. 111, 923-932; quiz 933.

Long, E. O. (2011). ICAM-1: getting a grip on leukocyte adhesion. J. Immunol. 186, 5021-5023.

Lucey, D. R., Nicholson-Weller, A., and Weller, P. F. (1989). Mature human eosinophils have the capacity to express HLA-DR. Proc. Natl. Acad. Sci. U.S.A. 86, 1348-1351.

MacKenzie, J. R., Mattes, J., Dent, L. A., and Foster, P. S. (2001). Eosinophils promote allergic disease of the lung by regulating $\mathrm{CD} 4(+)$ Th2 lymphocyte function. J. Immunol. 167, 3146-3155.

Magalhaes, E. S., Paiva, C. N., Souza, H. S., Pyrrho, A. S., Mourao-Sa,
D., Figueiredo, R. T., et al. (2009). Macrophage migration inhibitory factor is critical to interleukin-5driven eosinophilopoiesis and tissue eosinophilia triggered by Schistosoma mansoni infection. FASEB J. 23, 1262-1271.

Makino, S., and Fukuda, T. (1995). Eosinophils and allergy in asthma. Allergy Proc. 16, 13-21.

Masur, S. K., Dewal, H. S., Dinh, T. T., Erenburg, I., and Petridou, S. (1996). Myofibroblasts differentiate from fibroblasts when plated at low density. Proc. Natl. Acad. Sci. U.S.A. 93, 4219-4223.

Matsunaga, Y., Shono, M., Takahashi, M., Tsuboi, Y., Ogawa, K., and Yamada, T. (2000). Regulation of lymphocyte proliferation by eosinophils via chymotrypsin-like protease activity and adhesion molecule interaction. Br. J. Pharmacol. 130, 1539-1546.

Mattes, J., Yang, M., Mahalingam, S., Kuehr, J., Webb, D. C., Simson, L., et al. (2002). Intrinsic defect in $\mathrm{T}$ cell production of interleukin (IL)13 in the absence of both IL-5 and eotaxin precludes the development of eosinophilia and airways hyperreactivity in experimental asthma. $J$. Exp. Med. 195, 1433-1444.

Matthews, A. N., Friend, D. S., Zimmermann, N., Sarafi, M. N., Luster, A. D. Pearlman, E., et al. (1998). Eotaxin is required for the baseline level of tissue eosinophils. Proc. Natl. Acad. Sci. U.S.A. 95, 6273-6278.

Maurya, V., Gugnani, H. C., Sarma, P. U., Madan, T., and Shah, A. (2005). Sensitization to Aspergillus antigens and occurrence of allergic bronchopulmonary aspergillosis in patients with asthma. Chest 127, 1252-1259.

Mawhorter, S. D., Pearlman, E., Kazura, J. W., and Boom, W. H. (1993). Class II major histocompatibility complex molecule expression on murine eosinophils activated in vivo by Brugia malayi. Infect. Immun. 61, 5410-5412.

McMillan, S. J., and Lloyd, C. M. (2004). Prolonged allergen challenge in mice leads to persistent airway remodelling. Clin. Exp. Allergy 34, 497-507.

McMillan, S. J., Xanthou, G., and Lloyd, C. M. (2005). Manipulation of allergen-induced airway remodeling by treatment with anti-TGFbeta antibody: effect on the Smad signaling pathway. J. Immunol. 174, 5774-5780.

McNagny, K., and Graf, T. (2002). Making eosinophils through subtle shifts in transcription factor expression. $J$. Exp. Med. 195, F43-F47.
Mendell, M. J., Mirer, A. G., Cheung, K., Tong, M., and Douwes, J. (2011). Respiratory and allergic health effects of dampness, mold, and dampness-related agents: a review of the epidemiologic evidence. Environ. Health Perspect. 119 748-756.

Menzies-Gow, A., Flood-Page, P., Sehmi, R., Burman, J., Hamid, Q., Robinson, D. S., et al. (2003). Anti-IL-5 (mepolizumab) therapy induces bone marrow eosinophil maturational arrest and decreases eosinophil progenitors in the bronchial mucosa of atopic asthmatics. J. Allergy Clin. Immunol. $111,714-719$.

Menzies-Gow, A. N., Flood-Page, P. T., Robinson, D. S., and Kay, A. B. (2007). Effect of inhaled interleukin-5 on eosinophil progenitors in the bronchi and bone marrow of asthmatic and non-asthmatic volunteers. Clin. Exp. Allergy 37, 1023-1032.

Minnicozzi, M., Duran, W. N., Gleich, G. J., and Egan, R. W. (1994). Eosinophil granule proteins increase microvascular macromolecular transport in the hamster cheek pouch. J. Immunol. 153, 2664-2670.

Minshall, E., Chakir, J., Laviolette, M., Molet, S., Zhu, Z., Olivenstein, R., et al. (2000). IL-11 expression is increased in severe asthma: association with epithelial cells and eosinophils. J. Allergy Clin. Immunol. 105, 232-238.

Minshall, E. M., Leung, D. Y., Martin, R. J., Song, Y. L., Cameron, L., Ernst, P., et al. (1997). Eosinophil-associated TGF-betal mRNA expression and airways fibrosis in bronchial asthma. Am. J. Respir. Cell Mol. Biol. 17, 326-333.

Mishra, A., Hogan, S. P., Lee, J. J., Foster, P. S., and Rothenberg, M. E. (1999). Fundamental signals that regulate eosinophil homing to the gastrointestinal tract. J. Clin. Invest. 103, 1719-1727.

Monteiro, R. C., Hostoffer, R. W., Cooper, M. D., Bonner, J. R., Gartland, G. L., and Kubagawa, H. (1993). Definition of immunoglobulin A receptors on eosinophils and their enhanced expression in allergic individuals. J. Clin. Invest. 92, 1681-1685.

Moqbel, R., Walsh, G. M., Nagakura, T., MacDonald, A. J., Wardlaw, A. J., Iikura, Y., et al. (1990). The effect of platelet-activating factor on IgE binding to, and IgEdependent biological properties of human eosinophils. Immunology 70 , 251-257. 
Mori, L., Bellini, A., Stacey, M. A., Schmidt, M., and Mattoli, S. (2005). Fibrocytes contribute to the myofibroblast population in wounded skin and originate from the bone marrow. Exp. Cell Res. 304, 81-90.

Morita, E., Schroder, J. M., and Christophers, E. (1989). Differential sensitivities of purified human eosinophils and neutrophils to defined chemotaxins. Scand. J. Immunol. 29, 709-716.

Motegi, Y., and Kita, H. (1998). Interaction with secretory component stimulates effector functions of human eosinophils but not of neutrophils. J. Immunol. 161, 4340-4346.

Mould, A. W., Matthaei, K. I., Young, I. G., and Foster, P. S. (1997). Relationship between interleukin-5 and eotaxin in regulating blood and tissue eosinophilia in mice. J. Clin. Invest. 99, 1064-1071.

Muessel, M. J., Scott, K. S., Friedl, P., Bradding, P., and Wardlaw, A. J. (2008). CCL11 and GM-CSF differentially use the Rho GTPase pathway to regulate motility of human eosinophils in a three-dimensional microenvironment. J. Immunol. 180, 8354-8360.

Munitz, A., Bachelet, I., Eliashar, R., Khodoun, M., Finkelman, F. D., Rothenberg, M. E., et al. (2006). CD48 is an allergen and IL-3induced activation molecule on eosinophils. J. Immunol. 177, 77-83.

Munitz, A., Bachelet, I., Fraenkel, S., Katz, G., Mandelboim, O., Simon, H. U., et al. (2005). 2B4 (CD244) is expressed and functional on human eosinophils. J. Immunol. 174, 110-118.

Munoz, N. M., Douglas, I., Mayer, D., Herrnreiter, A., Zhu, X., and Leff, A. R. (1997). Eosinophil chemotaxis inhibited by 5 -lipoxygenase blockade and leukotriene receptor antagonism. Am. J. Respir. Crit. Care Med. 155, 1398-1403.

Murdock, B. J., Falkowski, N. R., Shreiner, A. B., Akha, A. A., McDonald, R. A., White, E. S., et al. (2012). Interleukin-17 drives pulmonary eosinophilia following repeated exposure to Aspergillus fumigatus conidia. Infect. Immun. 80, 1424-1436.

Murdock, B. J., Shreiner, A. B., McDonald, R. A., Osterholzer, J. J., White, E. S., Toews, G. B., et al. (2011). Coevolution of $\mathrm{TH} 1, \mathrm{TH} 2$, and TH17 responses during repeated pulmonary exposure to Aspergillus fumigatus conidia. Infect. Immun. 79, 125-135.

Nakajima, T., Yamada, H., Iikura, M., Miyamasu, M., Izumi, S., Shida, H., et al. (1998). Intracellular localization and release of eotaxin from normal eosinophils. FEBS Lett. 434, 226-230.

Nassenstein, C., Braun, A., Nockher, W. A., and Renz, H. (2005). Neurotrophin effects on eosinophils in allergic inflammation. Curr. Allergy Asthma Rep. 5, 204-211.

Nonaka, M., Nonaka, R., Woolley, K., Adelroth, E., Miura, K., Okhawara, Y., et al. (1995). Distinct immunohistochemical localization of IL4 in human inflamed airway tissues. IL-4 is localized to eosinophils in vivo and is released by peripheral blood eosinophils. J. Immunol. 155, 3234-3244.

Norgauer, J., Dobos, G., Kownatzki, E., Dahinden, C., Burger, R., Kupper, R., et al. (1993). Complement fragment $\mathrm{C} 3 \mathrm{a}$ stimulates $\mathrm{Ca} 2+$ influx in neutrophils via a pertussis-toxinsensitive G protein. Eur. J. Biochem. 217, 289-294.

Numao, T., and Agrawal, D. K. (1992). Neuropeptides modulate human eosinophil chemotaxis. J. Immunol. 149, 3309-3315.

O’Brien, H. E., Parrent, J. L., Jackson, J. A., Moncalvo, J. M., and Vilgalys, R. (2005). Fungal community analysis by large-scale sequencing of environmental samples. Appl. Environ. Microbiol. 71, 5544-5550.

O’Byrne, P. M., Inman, M. D., and Parameswaran, K. (2001). The trials and tribulations of IL-5, eosinophils, and allergic asthma. J. Allergy Clin. Immunol. 108, 503-508.

O’Donnell, M. C., Ackerman, S. J., Gleich, G. J., and Thomas, L. L. (1983). Activation of basophil and mast cell histamine release by eosinophil granule major basic protein. J. Exp. Med. 157, 1981-1991.

Ohkawara, Y., Lim, K. G., Xing, Z., Glibetic, M., Nakano, K., Dolovich, J., et al. (1996). CD40 expression by human peripheral blood eosinophils. J. Clin. Invest. 97, 1761-1766.

Ohkawara, Y., Tamura, G., Iwasaki, T., Tanaka, A., Kikuchi, T., and Shirato, K. (2000). Activation and transforming growth factor-beta production in eosinophils by hyaluronan. Am. J. Respir. Cell Mol. Biol. 23, 444-451.

Okigami, H., Takeshita, K., Tajimi, M., Komura, H., Albers, M., Lehmann, T. E., et al. (2007). Inhibition of eosinophilia in vivo by a small molecule inhibitor of very late antigen (VLA)-4. Eur. J. Pharmacol. 559, 202-209.

Ono, S. J., Nakamura, T., Miyazaki, D., Ohbayashi, M., Dawson, M., and Toda, M. (2003). Chemokines: roles in leukocyte development, trafficking, and effector function. J. Allergy Clin. Immunol. 111, 1185-1199; quiz 1200.

Palframan, R. T., Collins, P. D., Williams, T. J., and Rankin, S. M. (1998). Eotaxin induces a rapid release of eosinophils and their progenitors from the bone marrow. Blood 91, 2240-2248.

Paplinska, M., Grubek-Jaworska, H., and Chazan, R. (2007). Role of eotaxin in the pathophysiology of asthma. Pneumonol. Alergol. Pol. 75, 180-185.

Park, J. H., Cox-Ganser, J. M., Kreiss, K., White, S. K., and Rao, C. Y. (2008). Hydrophilic fungi and ergosterol associated with respiratory illness in a water-damaged building. Environ. Health Perspect. 116, 45-50.

Pearlman, D. S. (1999). Pathophysiology of the inflammatory response. J. Allergy Clin. Immunol. 104, S132S137.

Piliponsky, A. M., Gleich, G. J., Bar I., and Levi-Schaffer, F. (2002). Effects of eosinophils on mast cells: a new pathway for the perpetuation of allergic inflammation. $\mathrm{Mol}$. Immunol. 38, 1369.

Ponath, P. D., Qin, S., Post, T. W., Wang, J., Wu, L., Gerard, N. P., et al. (1996). Molecular cloning and characterization of a human eotaxin receptor expressed selectively on eosinophils. J. Exp. Med. 183, 2437-2448.

Pongracic, J. A., O’Connor, G. T., Muilenberg, M. L., Vaughn, B., Gold, D. R., Kattan, M., et al. (2010). Differential effects of outdoor versus indoor fungal spores on asthma morbidity in inner-city children. J. Allergy Clin. Immunol. 125, 593-599.

Pope, S. M., Zimmermann, N., Stringer, K. F., Karow, M. L., and Rothenberg, M. E. (2005). The eotaxin chemokines and CCR3 are fundamental regulators of allergeninduced pulmonary eosinophilia. J. Immunol. 175, 5341-5350.

Rahman, M. S., Yamasaki, A., Yang, J., Shan, L., Halayko, A. J., and Gounni, A. S. (2006). IL-17A induces eotaxin1/CC chemokine ligand 11 expression in human airway smooth muscle cells: role of MAPK (Erk1/2, JNK, and p38) pathways. J. Immunol. 177, 4064-4071.

Ramaprakash, H., Ito, T., Standiford, T. J., Kunkel, S. L., and Hogaboam, C. M. (2009). Tolllike receptor 9 modulates immune responses to Aspergillus fumigatus conidia in immunodeficient and allergic mice. Infect. Immun. 77, 108-119.
Rand, T. H., Silberstein, D. S., Kornfeld, H., and Weller, P. F. (1991). Human eosinophils express functional interleukin 2 receptors. J. Clin. Invest. 88 , 825-832.

Reed, C. E. (1994). The importance of eosinophils in the immunology of asthma and allergic disease. Ann. Allergy 72, 376-380.

Reese, T. A., Liang, H. E., Tager, A. M., Luster, A. D., Van Rooijen, N., Voehringer, D., et al. (2007). Chitin induces accumulation in tissue of innate immune cells associated with allergy. Nature 447, 92-96.

Richter, A., Puddicombe, S. M., Lordan, J. L., Bucchieri, F., Wilson, S. J., Djukanovic, R., et al (2001). The contribution of interleukin (IL)-4 and IL-13 to the epithelial-mesenchymal trophic unit in asthma. Am. J. Respir. Cell Mol. Biol. 25, 385-391.

Robinson, D. S., Damia, R., Zeibecoglou, K., Molet, S., North, J., Yamada, T. et al. (1999). CD34(+)/interleukin5Ralpha messenger RNA+ cells in the bronchial mucosa in asthma: potential airway eosinophil progenitors. Am. J. Respir. Cell Mol. Biol. 20, 9-13.

Roglic, A., Prossnitz, E. R., Cavanagh, S. L., Pan, Z., Zou, A., and Ye, R. D. (1996). cDNA cloning of a novel $\mathrm{G}$ protein-coupled receptor with a large extracellular loop structure. Biochim. Biophys. Acta 1305, 39-43.

Rosenberg, H. F., Ackerman, S. J., and Tenen, D. G. (1989). Human eosinophil cationic protein. Molecular cloning of a cytotoxin and helminthotoxin with ribonuclease activity. J. Exp. Med. 170, 163-176.

Rosenberg, H. F., Dyer, K. D., and Foster, P. S. (2013). Eosinophils: changing perspectives in health and disease. Nat. Rev. Immunol. 13, 9-22.

Rosenberg, H. F., Phipps, S., and Foster, P. S. (2007). Eosinophil trafficking in allergy and asthma. J. Allergy Clin. Immunol. 119, 1303-1310; quiz 1311-1302.

Rot, A., Krieger, M., Brunner, T., Bischoff, S. C., Schall, T. J., and Dahinden, C. A. (1992). RANTES and macrophage inflammatory protein 1 alpha induce the migration and activation of normal human eosinophil granulocytes. J. Exp. Med. 176, 1489-1495.

Rothenberg, M. E., and Hogan, S. P. (2006). The eosinophil. Annu. Rev. Immunol. 24, 147-174.

Rothenberg, M. E., MaClean, J. A., Pearlman, E., Luster, A. D., and Leder, P. (1997). Targeted disruption of the chemokine eotaxin partially reduces 
antigen-induced tissue eosinophilia. J. Exp. Med. 185, 785-790.

Rothenberg, M. E., Ownbey, R., Mehlhop, P. D., Loiselle, P. M., Van De Rijn, M., Bonventre, J. V., et al. (1996). Eotaxin triggers eosinophilselective chemotaxis and calcium flux via a distinct receptor and induces pulmonary eosinophilia in the presence of interleukin 5 in mice. Mol. Med. 2, 334-348.

Rozell, M. D., Erger, R. A., and Casale, T. B. (1996). Isolation technique alters eosinophil migration response to IL8. J. Immunol. Methods 197, 97-107. Sahai, E., and Marshall, C. J. (2003). Differing modes of tumour cell invasion have distinct requirements for Rho/ROCK signalling and extracellular proteolysis. Nat. Cell Biol. 5, 711-719.

Saito, H., Matsumoto, K., Denburg, A. E., Crawford, L., Ellis, R., Inman, M. D., et al. (2002). Pathogenesis of murine experimental allergic rhinitis: a study of local and systemic consequences of IL-5 deficiency. $J$. Immunol. 168, 3017-3023.

Samarasinghe, A.E., Hoselton, S. A., and Schuh, J. M. (2010). Spatio-temporal localization of vasoactive intestinal peptide and neutral endopeptidase in allergic murine lungs. Regul. Pept. 164, 151-157.

Samarasinghe, A. E., Hoselton, S. A., and Schuh, J. M. (2011a). The absence of VPAC2 leads to aberrant antibody production in Aspergillus fumigatus sensitized and challenged mice. Peptides 32, 131-137.

Samarasinghe, A.E., Hoselton, S. A., and Schuh, J. M. (2011b). A comparison between intratracheal and inhalation delivery of Aspergillus fumigatus conidia in the development of fungal allergic asthma in C57BL/6 mice. Fungal Biol. 115, 21-29.

Sanderson, C. J. (1992). Interleukin-5, eosinophils, and disease. Blood 79, 3101-3109.

Sanmugalingham, D., De Vries, E., Gauntlett, R., Symon, F. A., Bradding, P., and Wardlaw, A. J. (2000). Interleukin-5 enhances eosinophil adhesion to bronchial epithelial cells. Clin. Exp. Allergy 30, 255-263.

Santiago, H. d. C., Bennuru, S., Ribeiro, J. M., and Nutman, T. B. (2012). Structural differences between human proteins and aero- and microbial allergens define allergenicity. PLoS ONE 7:e40552. doi:10.1371/journal.pone.0040552

Sarinho, E., and Cruz, A. A. (2006). Anti-IgE monoclonal antibody for the treatment of the asthma and other manifestations related to allergic diseases. J. Pediatr. (Rio J.) 82, S127-S132.

Schmitz, A. A., Govek, E. E., Bottner, B., and Van Aelst, L. (2000). Rho GTPases: signaling, migration, and invasion. Exp. Cell Res. 261, 1-12.

Schnyder-Candrian, S., Togbe, D., Couillin, I., Mercier, I., Brombacher, F., Quesniaux, V., et al. (2006). Interleukin-17 is a negative regulator of established allergic asthma. $J$. Exp. Med. 203, 2715-2725.

Schuh, J. M., Blease, K., Bruhl, H., Mack, M., and Hogaboam, C. M. (2003). Intrapulmonary targeting of RANTES/CCL5-responsive cells prevents chronic fungal asthma. Eur. J. Immunol. 33, 3080-3090.

Schuh, J. M., Blease, K., Kunkel, S. L., and Hogaboam, C. M. (2002). Eotaxin/CCL11 is involved in acute, but not chronic, allergic airway responses to Aspergillus fumigatus. Am. J. Physiol. Lung Cell Mol. Physiol. 283, L198-L204.

Schwartz, H. J., Citron, K. M., Chester, E. H., Kaimal, J., Barlow, P. B., Baum, G. L., et al. (1978). A comparison of the prevalence of sensitization to Aspergillus antigens among asthmatics in Cleveland and London. J. Allergy Clin. Immunol. 62, 9-14.

Schwartz, R. H. (2001). Immunology. It takes more than two to tango. Nature 409, 31-32.

Schweizer, R. C., Van Kessel-Welmers, B. A., Warringa, R. A., Maikoe, T., Raaijmakers, J. A., Lammers, J. W., et al. (1996). Mechanisms involved in eosinophil migration. Platelet-activating factor-induced chemotaxis and interleukin-5induced chemokinesis are mediated by different signals. J. Leukoc. Biol. 59, 347-356.

Sedgwick, J. B., Calhoun, W. J., Vrtis, R. F., Bates, M. E., McAllister, P. K., and Busse, W. W. (1992). Comparison of airway and blood eosinophil function after in vivo antigen challenge. J. Immunol. 149, 3710-3718.

Sehmi, R., Wardlaw, A. J., Cromwell, O., Kurihara, K., Waltmann, P., and Kay, A. B. (1992). Interleukin-5 selectively enhances the chemotactic response of eosinophils obtained from normal but not eosinophilic subjects. Blood 79, 2952-2959.

Seminario, M. C., Saini, S. S., MacGlashan, D. W. Jr., and Bochner, B. S. (1999). Intracellular expression and release of Fc epsilon RI alpha by human eosinophils. J. Immunol. 162, 6893-6900.

Shi, H. Z., Humbles, A., Gerard, C., Jin, Z., and Weller, P. F. (2000). Lymph node trafficking and antigen presentation by endobronchial eosinophils. J. Clin. Invest. 105, 945-953.

Simson, L., and Foster, P. S. (2000). Chemokine and cytokine cooperativity: eosinophil migration in the asthmatic response. Immunol. Cell Biol. 78, 415-422.

Smit, J. J., and Lukacs, N. W. (2006). A closer look at chemokines and their role in asthmatic responses. Eur. J. Pharmacol. 533, 277-288.

Southam, D. S., Widmer, N., Ellis, R., Hirota, J. A., Inman, M. D., and Sehmi, R. (2005). Increased eosinophil-lineage committed progenitors in the lung of allergenchallenged mice. J. Allergy Clin Immunol. 115, 95-102.

Sung, K. P., Yang, L., Kim, J., Ko, D. Stachnick, G., Castaneda, D., et al. (2000). Eotaxin induces a sustained reduction in the functional adhesive state of very late antigen 4 for the connecting segment 1 region of fibronectin. J. Allergy Clin. Immunol. 106, 933-940.

Tachimoto, H., and Bochner, B. S. (2000). The surface phenotype of human eosinophils. Chem. Immunol. 76, 45-62.

Takafuji, S., Tadokoro, K., Ito, K., and Nakagawa, T. (1998). Release of granule proteins from human eosinophils stimulated with mastcell mediators. Allergy 53, 951-956.

Takamoto, M., and Sugane, K. (1995). Synergism of IL-3, IL-5, and GMCSF on eosinophil differentiation and its application for an assay of murine IL-5 as an eosinophil differentiation factor. Immunol. Lett. 45, 43-46.

Tamura, N., Ishii, N., Nakazawa, M., Nagoya, M., Yoshinari, M., Amano, T., et al. (1996). Requirement of CD80 and CD86 molecules for antigen presentation by eosinophils. Scand. J. Immunol. 44, 229-238.

Tanaka, H., Komai, M., Nagao, K., Ishizaki, M., Kajiwara, D., Takatsu, K., et al. (2004). Role of interleukin-5 and eosinophils in allergen-induced airway remodeling in mice. Am. $J$. Respir. Cell Mol. Biol. 31, 62-68.

Tavernier, J., Van Der Heyden, J., Verhee, A., Brusselle, G., Van Ostade, X., Vandekerckhove, J., et al. (2000). Interleukin 5 regulates the isoform expression of its own receptor alphasubunit. Blood 95, 1600-1607.

Templeton, S. P., Buskirk, A. D., Green, B. J., Beezhold, D. H., and Schmechel, D. (2010). Murine models of airway fungal exposure and allergic sensitization. Med. Mycol. 48, 217-228.

Tenscher, K., Metzner, B., Schopf, E. Norgauer, J., and Czech, W. (1996).
Recombinant human eotaxin induces oxygen radical production, $\mathrm{Ca}(2+)$-mobilization, actin reorganization, and CD11b upregulation in human eosinophils via a pertussis toxin-sensitive heterotrimeric guanine nucleotide-binding protein. Blood 88, 3195-3199.

Traynor, T. R., and Huffnagle, G. B. (2001). Role of chemokines in fungal infections. Med. Mycol. 39, 41-50.

Trivedi, S. G., and Lloyd, C. M. (2007). Eosinophils in the pathogenesis of allergic airways disease. Cell. Mol. Life Sci. 64, 1269-1289.

Ueno, M., Watanabe, K., Tsurufuji, S. and Hirashima, M. (1994). Effects of eosinophilotropic cytokines on differentiation of an eosinophil cell line, YY-1. Int. Arch. Allergy Immunol. 104 Suppl 1, 60-62.

Uhm, T. G., Kim, B. S., and Chung, I. Y. (2012). Eosinophil development, regulation of eosinophil-specific genes, and role of eosinophils in the pathogenesis of asthma. Allergy Asthma Immunol. Res. 4, 68-79.

Umetsu, D. T., and DeKruyff, R. H. (2006). The regulation of allergy and asthma. Immunol. Rev. 212, 238-255.

Urban, C. F., Reichard, U., Brinkmann, V., and Zychlinsky, A. (2006). Neutrophil extracellular traps capture and kill Candida albicans yeast and hyphal forms. Cell. Microbiol. 8, 668-676.

Van Dyken, S. J., Garcia, D., Porter, P., Huang, X., Quinlan, P. J., Blanc, P. D., et al. (2011). Fungal chitin from asthma-associated home environments induces eosinophilic lung infiltration. J. Immunol. 187, 2261-2267.

Venge, P. (2010). The eosinophil and airway remodelling in asthma. Clin. Respir. J. 4(Suppl. 1), 15-19.

Verstraelen, S., Bloemen, K., Nelissen, I., Witters, H., Schoeters, G., and Van Den Heuvel, R. (2008). Cell types involved in allergic asthma and their use in in vitro models to assess respiratory sensitization. Toxicol. In vitro 22, 1419-1431.

Vestweber, D. (2012). Novel insights into leukocyte extravasation. Curr. Opin. Hematol. 19, 212-217.

Vicencio, A. G., Foley, E. A., Bush, D., Tsirilakis, K., Santiago, M. T., Stone, A., et al. (2012). Severe asthma with fungal sensitization in children: characterization of a new pediatric asthma sub-phenotype. Am. J. Respir. Crit. Care Med. 185, A4068.

von Kockritz-Blickwede, M., Goldmann, O., Thulin, P., Heinemann, K., Norrby-Teglund, A., Rohde, M., et al. (2008). Phagocytosis-independent 
antimicrobial activity of mast cells by means of extracellular trap formation. Blood 111, 3070-3080.

Walsh, G. M. (1999). Advances in the immunobiology of eosinophils and their role in disease. Crit. Rev. Clin. Lab. Sci. 36, 453-496.

Wardlaw, A. J., Brightling, C., Green, R., Woltmann, G., and Pavord, I. (2000). Eosinophils in asthma and other allergic diseases. Br. Med. Bull. 56, 985-1003.

Webster, S. J., Daigneault, M., Bewley, M. A., Preston, J. A., Marriott, H. M., Walmsley, S. R., et al. (2010). Distinct cell death programs in monocytes regulate innate responses following challenge with common causes of invasive bacterial disease. J. Immunol. 185, 2968-2979.

Weller, P. F. (2008). The immunobiology of eosinophils - it's a whole new world out there: an interview with Dr. Peter F. Weller. J. Leukoc. Biol. 83, 822-823.

Wicks, J., Haitchi, H. M., Holgate, S. T., Davies, D. E., and Powell, R. M. (2006). Enhanced upregulation of smooth muscle related transcripts by TGF beta2 in asthmatic (myo) fibroblasts. Thorax 61, 313-319.

Williams, T. J. (2004). The eosinophil enigma. J. Clin. Invest. 113, 507-509.

Woerly, G., Lacy, P., Younes, A. B., Roger, N., Loiseau, S., Moqbel, R., et al. (2002). Human eosinophils express and release IL-13 following CD28dependent activation. J. Leukoc. Biol. 72, 769-779.

Wu, W., Chen, Y., and Hazen, S. L. (1999). Eosinophil peroxidase nitrates protein tyrosyl residues. Implications for oxidative damage by nitrating intermediates in eosinophilic inflammatory disorders. J. Biol. Chem. 274, 25933-25944.

Xiao, T., Takagi, J., Coller, B. S., Wang, J. H., and Springer, T. A. (2004). Structural basis for allostery in integrins and binding to fibrinogenmimetic therapeutics. Nature 432, 59-67.

Ying, S., Meng, Q., Taborda-Barata, L., Corrigan, C. J., Barkans, J., Assoufi, B., et al. (1996). Human eosinophils express messenger RNA encoding RANTES and store and release biologically active RANTES protein. Eur. J. Immunol. 26, 70-76.

Yoon, J., Ponikau, J. U., Lawrence, C. B., and Kita, H. (2008). Innate antifungal immunity of human eosinophils mediated by a beta 2 integrin, CD11b. J. Immunol. 181, 2907-2915.

Yousefi, S., Gold, J. A., Andina, N., Lee, J. J., Kelly, A. M., Kozlowski, E., et al. (2008). Catapult-like release of mitochondrial DNA by eosinophils contributes to antibacterial defense. Nat. Med. 14, 949-953.

Yousefi, S., Hemmann, S., Weber, M., Holzer, C., Hartung, K., Blaser, K., et al. (1995). IL-8 is expressed by human peripheral blood eosinophils. Evidence for increased secretion in asthma. J. Immunol. 154, 5481-5490.

Zheutlin, L. M., Ackerman, S. J., Gleich, G. J., and Thomas, L. L. (1984). Stimulation of basophil and rat mast cell histamine release by eosinophil granule-derived cationic proteins. J. Immunol. 133 2180-2185.
Conflict of Interest Statement: The authors declare that the research was conducted in the absence of any commercial or financial relationships that could be construed as a potential conflict of interest.

Received: 30 October 2012; accepted: 10 January 2013; published online: $01 \mathrm{Feb}$ ruary 2013.

Citation: Ghosh S, Hoselton SA, Dorsam GP and Schuh JM (2013) Eosinophils in fungus-associated allergic pulmonary disease. Front. Pharmacol. 4:8. doi: 10.3389/fphar.2013.00008

This article was submitted to Frontiers in Experimental Pharmacology and Drug Discovery, a specialty of Frontiers in Pharmacology.

Copyright (c) 2013 Ghosh, Hoselton, Dorsam and Schuh. This is an openaccess article distributed under the terms of the Creative Commons Attribution License, which permits use, distribution and reproduction in other forums, provided the original authors and source are credited and subject to any copyright notices concerning any third-party graphics etc. 